\title{
La evolución del régimen fiscal y análisis del régimen actual de la inversión de portafolio del exterior
}

\author{
Evolution of the Tax Regime and \\ Analysis of the Current Regime of \\ the External Portfolio Investment
}

\section{Evolução do regime fiscal e análise do regime atual do investimento da carteira externa}

\author{
Alba Janette Cardona Nieto ${ }^{1}$
}

\section{Resumen}

Esta monografía hace un análisis de los posibles efectos que puede traer la norma fiscal en la regulación del mercado de capitales, concretamente en lo referente a la inversión extranjera de portafolio regulado en el Artículo 18-1 del Estatuto Tributario. El trabajo se compone de dos partes, la primera hace un acercamiento a las nociones fundamentales que integran el mercado de capitales, y en la segunda un análisis de la evolución normativa del régimen especial de la inversión de portafolio extranjero desde la Ley 490 de 1990 hasta la Ley de Financiamiento expedida en el año 2018. Así mismo, se hace un análisis del comportamiento de algunas operaciones en los años en que se han presentado reformas tributarias, de datos obtenidos de la Superintendencia Financiera.

Palabras clave: Inversión de Capital de Exterior, Operaciones de Portafolio de Inversión extranjera y Artículo 18-1 del ET.
Abstract
This monograph makes an analysis on the possible effects that the fiscal rule can have on the regulation of the capital market, spe- cifically, with regard to foreign investment

${ }^{1}$ Abogada de la Universidad Libre de Colombia, con Especialización en Derecho Tributario, Derecho Aduanero y Comercio Exterior y Derecho Comercial de la Universidad Nuestra Señora del Rosario, Maestría en Derecho Tributario de la Universidad Externado de Colombia.Correo-e: janettc6@gmail.com DOI: https://doi.org/10.18601/16926722.n15.02 
of portfolio regulated in Article 18-1 of the Tax Statute. The document is composed of two chapters, the first one brings together the fundamental notions that make up the capital market, and the second one makes an analysis of the normative evolution of the special regime of foreign portfolio investment from Law 490 of 1990 to the Financing Law issued in 2018. Likewise, an analysis is made of the behavior of some operations in the years in which tax reforms have been presented, according to the data obtained from the Financial Superintendency.

Keywords: Foreign Capital Investment, Foreign Investment Portfolio Operations and Article 18-1 of the ET.

\section{Resumo}

Esta monografia faz uma análise sobre os possíveis efeitos que a regra fiscal pode ter na regulação do mercado de capitais, especificamente, no que diz respeito ao investimento estrangeiro de carteira regulado no Art. 18-1 do Estatuto Tributário. O documento é composto por dois capítulos, o primeiro reúne as noções fundamentais que compõem o mercado de capitais e o segundo faz uma análise da evolução normativa do regime especial de investimento estrangeiro em carteira, desde a Lei 490 de 1990 até o Financiamento. Lei emitida em 2018. Da mesma forma, é feita uma análise do comportamento de algumas operações nos anos em que as reformas tributárias foram apresentadas, de acordo com os dados obtidos pela Superintendência Financeira.

Palavras-chave: Investimento de Capital Estrangeiro, Operações de Carteira de Investimento Estrangeiro e Artigo 18-1 da ET.

\section{Introducción}

El mercado de valores tiene una gran importancia en la economía mundial, considerándose como una gran herramienta de integración económica frente a la liberalización del comercio y en general frente a la globalización de la economía, que permite el apalancamiento de las empresas del sector real y con ello la posibilidad de que el inversionista consiga liquidez de manera expedita a bajos costos, ofreciéndole grandes herramientas o alternativas a través de diferentes operaciones de mercado que se ajustan a la necesidad que se tiene particularmente en cada caso.

En este trabajo se hará el análisis de uno de los componentes que integran la regulación del mercado y que tiene gran influencia en la toma de decisión de un inversionista para invertir en determinado país, como lo es la regulación fiscal.

La regulación normativa en la inversión de portafolio del exterior ha sido dinámica en los últimos años; sin embargo, en materia fiscal esta se ha visto un poco quedada en el tiempo, pues solo hasta el año 2012, con la Ley 1607, se logró establecer un marco normativo íntegro que atienda a la realidad del mercado, siendo a partir del estudio de esta modificación normativa que se realizó al Artículo 18-1 del Estatuto Tributario, el punto de partida para analizar la influencia de la norma fiscal en la dinámica de este mercado.

Este escrito se compone de tres partes, con las cuales se abordará el estudio legislativo fiscal de las diferentes etapas normativas de la inversión de portafolio extranjera. La primera en la que analizará la evolución del 
Derecho fiscal a raíz del avance económico del mercado de valores; la segunda que inicia con la Ley 49 de 1990, por medio de la cual se adicionó al ET, el Artículo 18-1 hasta la reforma que trajo la Ley 223 de 1995, y la tercera analizará la regulación actual que inicia con la Ley 1607 de 2012 hasta la Ley de financiamiento.

\section{Evolución del mercado de valores que implica el desarrollo en la norma fiscal}

La pacificación económica después de la Segunda Guerra Mundial permitió el restablecimiento del libre comercio y las integraciones económicas, lo que generó una nueva evolución jurídica que se vio afectada por algunos eventos como el liberalismo económico y las demandas de legitimidad política a los diferentes mecanismos por los que transita la globalización (Álvarez Zárate y Grando, 2013).

La globalización conllevó la integración de economías, así como de los mercados, lo que trajo como consecuencia la necesidad de permitir un movimiento libre de capitales, el desarrollo tecnológico y de las telecomunicaciones y la creciente importancia de la gestión de riesgos y del desarrollo, protección y explotación de la propiedad intelectual, que han tenido un impacto importante en la manera como se desarrollan las actividades transfronterizas, fomenta la innovación y ha facilitado que millones de personas salgan de la pobreza (OCDE, 2014).

Es así como con la globalización y el movimiento de capitales el mercado de valores ha tenido un gran desarrollo en las últimas décadas; la creación de nuevas operaciones en el mercado ha implicado que ahora se encuentren nuevos actores, nuevos contratos y nuevas figuras con las cuales se movilizan los capitales, se financia el sector deficitario, se gestiona el riesgo y se reducen los costos de transacción, definidos por Eggertsson citado por Amador Cabra como aquellos gastos que surgen cuando se intercambian los derechos de propiedad sobre activos económicos y se ejercen sus derechos exclusivos (Monroy Cely, Amador Cabra y Blanco Varón, 2014). Sin embargo, esta dinámica económica va acompañada por un conjunto de normas e instituciones jurídicas que le permiten regular los actos y operaciones allí utilizadas con el objeto de que todos los actores conozcan las reglas de juego en la dinámica del mercado.

Conviene indicar que, en materia económica, lo primero que surgen son los hechos, las operaciones o transacciones y muchas veces la costumbre comercial en el mercado, lo que lleva a que la norma jurídica entre a regularlo a través de la inclusión en el Derecho positivo, buscando de esta manera atender las necesidades de los mercados y resolver los problemas que este presente. Lo anterior, también sucede con la regulación impositiva, que en algunas ocasiones resulta demasiado rezagada a la dinámica económica y a la velocidad del mercado.

Ahora bien, la regulación del mercado de valores, concretamente en relación con el portafolio de inversión extranjera, ha tenido un gran avance en la última década en Colombia, ya que, al convertirse en un mercado más dinámico, se ha visto la necesidad por parte del Estado de regular las nuevas operaciones contractuales que en él resultan. Claro ejemplo de ello se puede observar en la expedición de la Ley 964 de 2005, que estableció 
todas las disposiciones marco del mercado de valores, o el Decreto 119 de 2017, que modifica el Decreto 1068 de 2015, en lo relacionado con el régimen general de la inversión de capitales del exterior en Colombia y de las inversiones colombianas en el exterior, así como en valores listados en los sistemas de cotización de valores del extranjero.

Bajo el anterior contexto, la regulación del mercado se vuelve importante y fundamental, pues se convierte en un incentivo para los agentes económicos en la medida que pueda ofrecer estímulos con el propósito de incrementar la producción, o en este caso, el intercambio de valores o la configuración de operaciones que lleven a emprender nuevas inversiones y aumentar la eficiencia global del mercado tal como puede entenderlo la teoría del análisis económico del derecho que juega un papel relevante, pues gracias a esta se identifican cuáles son las normas e instituciones que permiten mejorar el funcionamiento del mercado (Amador Cabra, Monroy Cely y Blanco Varón, 2014). Esta teoría permite que a través de la regulación normativa el mercado se dinamice, maximizando la riqueza y mejorando la eficiencia económica del mismo.

Sin embargo, la regulación del mercado de valores en Colombia, y podría decirse a nivel mundial, no son ruedas separadas que no atiendan a la fenomenología que ha traído consigo la globalización y la integración económica, pues la interdependencia económica y política requiere de respuestas globales y acciones conjuntas entre los Estados (Álvarez Zárate y Grando, 2013); es así como a través de organismos multilaterales como laOCDE o de regulaciones creadas porcomités, como los conocidos Acuerdos de Ba- silea, emiten recomendaciones o lineamientos estándar de índole financiero, lo que se denomina soft low, el cual en Colombia se integra a través del Derecho positivo o de circulares emitidas por el ente de control, es decir, la Superintendencia Financiera.

Así, la regulación del mercado financiero dentro del cual se localiza el mercado de valores y en el que se desarrolla el portafolio de inversión extranjera, se encuentra definido en el Derecho positivo, con lo cual se busca dar respuestas a los problemas y a las necesidades de los agentes económicos, lo que ha llevado a definir la regulación del sector financiero como una regulación finalista (Álvarez Zárate y Grando, 2013) tal como se presentó con la Ley Marco del Mercado de Valores -Ley 694 de 2005- o con el ya referido Decreto 119 de 2017.

El mercado financiero y en concreto el mercado de valores acompañado de la inversión extranjera que se maneja a través de portafolio, ha suscitado un mayor crecimiento en las últimas décadas, lo que lleva a que se requiera de una regulación no solo sobre las reglas de los operadores del mercado, de la autorregulación de este, sino también, de aquellos ámbitos que van dirigidos a permitirles a los Estados obtener una contraprestación por la generación de la riqueza en dichos entornos y sobre el cual este ejerce su poder tributario, reconocido en Colombia constitucionalmente y que consiste en esa facultad normativa de crear o establecer tributos, caracterizada por ser una actuación genérica, abstracta, indisponible, irrenunciable e imprescriptible que no se extingue con su ejercicio y que recae en el Congreso de la República así como en las entidades territoriales (Insignares, Piza y Zornoza , 2001). 
En materia de regulación tributaria en el sector financiero y concretamente en el portafolio de inversión extranjera, el Estado manifiesta todo su poder impositivo, en el cual muchas veces se pasa por alto el soft low o las recomendaciones realizadas por organismos como la OCDE, pues en materia de regulación impositiva, no solo juega como factor determinante la dinámica del mercado sino también la necesidad del recaudo del país para atender su gasto público y social. Es por lo anterior que los procesos de integración económica en América Latina resultan complejos, toda vez que cada Estado presenta una necesidad diferente no solo económica o social sino también impositiva o recaudatoria.

En América Latina se ha presentado un gran resultado en materia de integración bursátil a través del Mercado Integrado Latinoamericano - MILA, creado en el 2009, conformado por cuatro Estados como son: Colombia (los mayores representantes emisores en el MILA por parte de Colombia son: Ecopetrol, Bancolombia, Argos, Isagen y la BVC las cuales a su vez son las organizaciones más reconocidas en el proceso), Perú, Chile y México, y cuyo objetivo se deriva en la creación de un mercado regional con el objeto de transar títulos de renta variable de los cuatro países.

Sin embargo, pese al gran resultado en la integración de este mercado, aún se presenta un factor que no permite que se hable completamente de integración y que puede impedir que no sea tan dinámico y competitivo, como lo es la regulación impositiva de las operaciones allí desarrolladas, pues en este aspecto cada Estado ejerce su poder impositivo de acuerdo con su necesidad de recaudo o con la política económica que presenta. A modo de ejemplo, en el caso colombiano todavía se presenta una fuerte tarifa de retención en la fuente a título de renta, sin contar el impuesto a los dividendos establecido en la reciente reforma tributaria - Ley 1819 de 2016 que hace más costoso invertir en este país en títulos de renta variable, como las acciones.

Pese a lo anterior, en los países que integran este mercado latinoamericano se ha observado un gran crecimiento, que se puede evidenciar con los resultados que presentó el Banco Mundial sobre la los mercados de renta variable, citados en la obra realizada por el Instituto Colombiano de Derecho Tributario en el año 2017, conocida como “Tributación de los Mercados de Capitales en América Latina”, en el cual se indica que durante el periodo 2011-2015 respecto al mercado de renta variable la capitalización de mercado de empresas cotizadas fueron en Brasil el 34,9\% del PIB, en Colombia 38,8 \% del PIB, teniendo la mayor participación en Chile, en el cual fue del 90,4\% del PIB. En relación con el mercado de deuda (emisión de bonos y títulos representativos) se observa que este ha estado un poco más rezagado, en el que tienen mayor dinámica los títulos de deuda pública que los privados. De acuerdo con cifras del Foro Económico Mundial, los bonos de las economías emergentes solo representan el $14 \%$ del valor de mercado global.

\section{Regulación fiscal de la inversión de portafolio desde los 90 hasta el 2012}

El proceso de apertura económica iniciado en los años 90 con el cual se buscaba dejar a un lado el modelo proteccionista de la economía, se empezó a vislumbrar un fuerte cambio estructural del país, recono- 
cido constitucionalmente en el año 1991; así se acogieron los principios de libertad económica y de la libre competencia, con lo que se establecieron algunas reformas en los ámbitos como comercio exterior, régimen cambiario, política de inversión extranjera y en el ámbito fiscal dentro del cual se ubica el régimen tributario (Ramírez Molinares, 2011).

Dicha apertura económica no podría ser ajena a la regulación tributaria del mercado de valores o de capitales y en concreto de la inversión de portafolio que hay en Colombia.

De esta manera, la historia impositiva del portafolio de inversión extranjera tiene su génesis con la Ley 49 de 1990, por medio de la cual se adiciona al Estatuto Tributario el Artículo 18-1; en esta se habla por primera vez en el ordenamiento impositivo de la forma de gravar los fondos de inversión de capital extranjero, y este segmento de la historia de la regulación fiscal finaliza en el año 2012, con la reforma introducida con la Ley 1607 con la cual se definen reglas claras para gravar al inversionista extranjero.

\section{A. Ley 49 de 1990}

En los años 90, los países de América Latina buscaron crear y establecer diferentes herramientas con el objeto de atraer nuevos capitales existentes en los mercados internacionales a través de la conocida liberalización financiera, la privatización a través de ofertas públicas en las bolsas de valores, así como el establecimiento de medidas legales para desarrollar e incentivar este mercado.
Sin embargo, las medidas adoptadas por los mercados de países en desarrollo como el colombiano, tenían como objetivo inicial que el mercado de capitales proporcionara una financiación relativamente económica, movilizando el ahorro eficientemente hacia su uso más productivo y ofreciendo a los inversores oportunidades de inversión atractivas (De la Torre y Schmukler, 2008); es así como se incorporan al ordenamiento interno normas comunitarias (Decisiones Andinas) relacionadas con la inversión extranjera (o internacional) y se regularon aspectos determinantes para ello como los efectos tributarios sobre dichas inversiones.

En materia de regulación de la inversión extranjera en Colombia se expidió la Ley 9 de 1991, "Por la cual se dictan normas generales a las que deberá sujetarse el Gobierno Nacional para regular los cambios internacionales y se adoptan medidas complementarias", conocida por algunos como la ley marco de la inversión extranjera, la cual iba en concordancia con los postulados de apertura económica, toda vez que buscaba propiciar la internacionalización de la economía colombiana con el fin de aumentar su competitividad en los mercados externos y, con ello, estimular la inversión de capitales del exterior en el país, estableciéndose de manera expresa el derecho de igualdad de trato para el inversionista extranjero frente al nacional.

De acuerdo con lo anterior y en concordancia con algunas Decisiones Andinas como la 292 y 293 de 1990, se expidió en el año de 1991 el Estatuto de Inversiones Internacionales a través de la Resolución $\mathrm{n}^{\circ} .51$ 
de 1991 del Consejo Nacional de Política Económica y Social - Conpes, en la cual se definen como inversiones internacionales aquellas inversiones realizadas en el territorio colombiano por parte de personas naturales no residentes en Colombia y personas extranjeras; y las inversiones realizadas por un residente del país en el extranjero o en zona franca colombiana. Este Estatuto de Inversiones dio un marco regulatorio a la inversión extranjera que permitió asentar algunos conceptos y tratamientos no solo de la inversión directa sino también de la indirecta y de portafolio.

Esta resolución también define al inversionista extranjero en general como la persona natural no residente en el país que realizara una inversión en territorio colombiano con recursos provenientes del exterior y se le reconocen los mismos derechos que se conceden a los inversionistas nacionales residentes, definiéndose de esa manera el principio de igualdad de trato y se consideró como no residente a la persona que probara su permanencia en el exterior, al menos por un año de manera ininterrumpida.

De esta manera, el Artículo 4 de la Resolución $\mathrm{n}^{\circ} .51$ de 1991 reconoce como inversión indirecta aquella realizada a través de algunos instrumentos como, por ejemplo, actos o contratos a través de los cuales el inversionista realizaba un aporte tangible o intangible a una empresa, sin llegar a tener participación accionaria en todo o en parte de ella; en esta inversión las rentas que esta generaba para su propietario dependían de las utilidades generadas por la empresa.

Por su parte, se definió la inversión de portafolio como aquella inversión extranje- ra que se efectuaba a través de la compra y venta de acciones y bonos obligatoriamente convertibles en acciones y otros valores negociables en las Bolsas de Valores; esta inversión debía realizarse a través de un fondo de inversión de capital extranjero, que podría ser individual o institucional y que tendría como único objeto realizar transacciones en el mercado público de valores.

Sin embargo, la inversión extranjera presentaba algunas limitaciones como, por ejemplo, ningún fondo de inversión de capital del exterior podía poseer el $10 \%$ o más del número de acciones con derecho a voto en circulación de una sociedad, limitación que se mantenía cuando la sociedad administrara varios fondos de inversión de capital extranjero en cuyo caso el conjunto de dichos fondos no podía poseer directa o indirectamente el $10 \%$ o más del número de acciones con derecho a voto en circulación de una sociedad.

La administración de este tipo de fondos era ejercida por una sociedad fiduciaria o comisionista de bolsa que sería la responsable solidaria de todas las obligaciones legales aplicables al fondo, como por ejemplo las de orden tributario y cambiario.

Ahora bien, respecto a la regulación tributaria de estos fondos, se observa en la exposición de motivos de la que sería la Ley 49 de 1990, que la movilización del ahorro hacia el sector productivo fue uno de los principales objetivos que llevó a la necesidad de la regulación tributaria de este tipo de inversión extranjera.

En el año de 1990, el sector financiero colombiano presentaba una deficiencia que 
radicaba en la ausencia de un fuerte mercado de capitales, a través de la colocación de títulos, acciones y bonos, lo anterior sin contar que la capacidad de ahorro era baja ya que de acuerdo con cifras presentadas en los Proyectos de Ley 70 y 111 del 1990 del Senado, este era del 19\% como proporción del PIB, en comparación con niveles del $25 \%$ y $30 \%$ en los países desarrollados.

En la ya referida exposición de motivos se evidenciaba la importancia que presentaban los fondos de inversión de capitales extranjeros, creados por el Artículo 30 de la Ley 78 de 1989, por medio de los cuales se empieza a manejar un constante y abundante flujo de capitales que permitirían una fuente de capital estable y ayudaría a inyectarle al sector productivo recursos y a reducir el endeudamiento de las empresas.

Es así como la norma fiscal entra a formar un papel importante en la dinámica de los fondos de inversión, importancia que se ve reflejada en la justificación de la adición del Artículo 18-1 del ET, que exponía que:

(...) la promoción de este tipo de fondos, demanda de una normativa clara en el tratamiento fiscal que los haga competitivos, de tal manera que no impidan su existencia real y sus benéficos impactos sobre el mercado bursátil, permitiendo agilidad en la ejecución de decisiones de inversión con la transparencia y autonomía del inversionista para conformar su portafolio (Congreso de la República, Exposición de Motivos Ley 49 de 1990, 1990).

Así mismo y con el objeto de regular e incentivar íntegramente el mercado de capitales, específicamente los fondos de inversión de capital extranjero, se estableció desgravar la utilidad obtenida en la enajenación de acciones, considerándola como utilidad no constitutiva de renta ni ganancia ocasional cuando estas han sido negociadas a través de una bolsa de valores. Lo anterior, buscaba que los accionistas tuvieran un incentivo para inscribir y negociar en la bolsa de valores sus títulos que con seguridad llevaría a obtener un mejor precio que el que se obtendría en una operación privada.

De esta manera, se establece por primera vez una regulación fiscal para la inversión de capital de extranjero a través de los fondos de inversión, con el Artículo 22 de la Ley 49 de 1990 -que adiciona al Estatuto Tributario el Artículo 18-1-, reconociéndose a estos fondos como contribuyentes del impuesto sobre la renta y complementarios (cualificación que luego fue eliminada del ordenamiento y que volvió a incluirse en el ordenamiento tributario hasta la reforma del 2012), es decir, de acuerdo con lo establecido en el Artículo segundo, el inversionista extranjero se considera como el sujeto pasivo respecto de quien se realiza el hecho generador de la obligación sustancial. Sin embargo, el responsable del tributo, recaía sobre una persona diferente al inversionista -situación que se mantente actualmente-, pues el encargado de liquidar y declarar la obligación tributaria era el administrador, es decir, la comisionista de bolsa o la sociedad fiduciaria.

Como elemento cuantitativo del hecho generador, es decir la base gravable, se dispuso una medición racional pero que no resulta de un concepto tributario o fiscal sino contable como lo es la utilidad comercial, es decir que la base gravable no era sobre el ingreso 
bruto, sino sobre una base liquidada, lo que significaba que al ingreso se le debería detraer aquellos gastos como por ejemplo los relacionados con los gastos de administración u otros que resultaren necesarios para obtener la ingreso y así aplicarle la tarifa establecida en el $12 \%$.

Conviene destacar que este impuesto, cuyo contribuyente era el inversionista extranjero, permanecía diferido hasta el momento en que efectivamente retornara al exterior la inversión, cuando se debería pagar a la Autoridad Fiscal el gravamen y el capital retornaría en dicho momento sin impuesto alguno, pues este ya se había causado en el momento de presentarse la utilidad comercial.

En el ámbito del ordenamiento internacional, Colombia contaba con algunos tratados para evitar la doble tributación dirigidos en su gran mayoría a no gravar o gravar con tarifa cero las rentas o utilidades obtenidas por empresas dirigidas al sector de transporte marítimo y aéreo. Entre los tratados que estaban vigentes en el año de 1990 se encuentran la Ley 124 de 1961 "Convenio con los Estados Unidos de América para eliminar la doble tributación en el transporte aéreo y marítimo", la Ley 16 de 1970 en la cual se adopta el Convenio entre Colombia y Alemania, la Ley 21 de 1972 que se refiere al convenio con Chile y la Ley 14 de 1981, en la cual se acoge el convenio suscrito con Italia.

Los mencionados convenios tenían un común denominador: establecían la exención o exclusión de impuestos directos o renta sobre las utilidades o ingresos de las sociedades que prestan servicios de transporte marítimo o aéreo pero en relación con las obtenidas en relación con su actividad; de esta manera las utilidades o ingresos obtenidos por la negociación de títulos como las acciones en el mercado público de valores a través de un portafolio por parte de esta sociedades estarían gravados al $12 \%$, pues dichas operaciones no formaban parte de su actividad.

En el Derecho comunitario, el Decreto 1551 de 1978, por medio del cual se ponen en aplicación los Convenios contenidos en los Anexos I y II de la Decisión 40 de la Comisión del Acuerdo de Cartagena, se impone el criterio de la fuente, es decir que la renta se grava única y exclusivamente en el lugar donde tales rentas tengan su fuente productora.

En relación con la inversión de portafolio del exterior, el literal b) del Artículo 12 del Anexo I de la Decisión Andina se establecía que en los títulos, acciones y otros valores la renta se gravaría en el país donde estos se hubieran emitido y respecto a los dividendos serían gravados en el lugar donde se encuentre domiciliada la empresa que los distribuye, regulación que aún se mantiene.

Asimismo, se establece la Decisión 291 de la CAN, en la cual se establecen algunas normas sobre la inversión de capital extranjero en los países andinos, en virtud de la cual se habla de la inversión directa y se determinan los derechos y obligaciones del inversionista extranjero y es en desarrollo de la referida norma comunitaria que se expide en Colombia la Resolución $n^{\circ} .51$ del 22 de octubre de 1991, preferida por el Consejo Nacional de Política Económica y Social - CONPES, en el cual se define al inversionista extranjero en general como la persona natural no residente en el país que realizara una inversión en te- 
rritorio colombiano con recursos provenientes del exterior y se le reconocen los mismos derechos que se conceden a los inversionistas nacionales residentes, definiéndose de esa manera el principio de igualdad de trato.

Esta resolución indicaba que se entendía por persona natural no residente en Colombia, la persona que probara su permanencia en el exterior, al menos por un año de manera ininterrumpida.

\section{B. Ley 6 de 1992. Artículo 2. Modifica el Artículo 18-1 del ET}

En el año de 1992 se presentó una reforma en el ordenamiento jurídico financiero de gran importancia para el mercado de capitales, concretamente para la forma de inversión extranjera a través de portafolio, puesto que a través de la Resolución 53 de ese año se modificó el Estatuto de Inversiones Internacionales, y con ello se habla en el ordenamiento jurídico de las cuentas colectivas.

Dos años después de la reforma tributaria presentada en el 90, sufrió la primera modificación el Artículo 18-1 del ET. Con esta reforma se buscó incentivar el mercado de capitales, concretamente el estímulo de los fondos de inversión colectiva, así como del desarrollo del mercado de títulos emitidos por el Estado, por lo que se modificó de manera sustancial el régimen tributario de los fondos de inversión de capital extranjero.

En primer lugar, pasaron los fondos de inversión de capital extranjero de ser considerados contribuyentes del impuesto sobre la renta a no ser contribuyentes, lo que significaría que el Estado en su potestad impositiva consideró que las utilidades que se obtuvieran en este tipo de fondos no se gravarían con el impuesto sobre la renta y complementarios; de esta manera, el legislador delimitó la definición genérica del hecho generador del impuesto mediante la creación del supuesto de no sujeción creado en lo norma (Piza Rodríguez, 2010), lo que implica en "teoría" que no nazca obligación tributaria sustancial alguna y que por ende, no se derive consecuencias jurídicas asociadas a la realización del hecho generador.

Lo mismo sucedía con la transferencia del capital invertido, el cual, siguiendo la misma regla del Artículo 22 de la Ley 49 de 1990, no se encontraba gravado por concepto del impuesto sobre la renta.

En segundo lugar, la reforma introducida con la Ley 6 de 1992, realizó una delimitación del hecho generador definiendo algunas reglas claras en materia de ingresos que tengan la calidad de rendimientos financieros o de dividendos que no hayan pagado impuestos en cabeza de la sociedad que los originó, pues en ese evento se configuraba el impuesto sobre la renta y la sociedad pagadora del dividendo o rendimiento era la responsable de pagar el impuesto constitutivo en una tarifa del $30 \%$, superior a la establecida en el año 90.

Sin embargo, la norma precisó que si los dividendos o rendimientos financieros ya tributaron el impuesto sobre la renta en la sociedad de donde provenían los mismos, estos no se encontraban gravados, pues como se indicó anteriormente, la norma general era que los partícipes de fondos de inversión de capital extranjero no residentes no eran contribuyentes del impuesto sobre la renta. 
También se distinguió entre el régimen de no sujeción del inversionista extranjero al régimen impositivo de la sociedad que administra el fondo, quién era contribuyente del impuesto por los ingresos que percibía por la actividad desarrollada en su calidad de administradora de este tipo de fondos.

\section{Ley 223 de 1995. Artículo 62 modifica el Artículo 18-1 ET}

Nuevamente en el año de 1995, a través de los Proyectos de Ley 023 de Cámara y 158 de Senado, se tramitó la reforma tributaria plasmada en la Ley 223. Entre los objetivos que permitiría incrementar la inversión extranjera se buscó actualizar las normas que regulaban las mismas con el objeto de eliminar las barreras o "trabas" que implicaban en algunas ocasiones la discriminación entre la inversión de capital foráneo y la nacional, pese a que en el campo financiero el año 1990 ya se hablaba de igualdad de trato para el inversionista extranjero o no residente frente al nacional, al reconocérsele los mismos derechos con la Resolución 51.

Por lo anterior, se modificó el Artículo 18-1 del ET, y con ella se crearon grandes inconvenientes para el inversionista de portafolio del exterior, considerándose como una reforma poco afortunada, cuya vigencia se presentó hasta el 31 de diciembre del año 2012.

El Artículo 62 de la Ley 223 de 1995 cualifica nuevamente como no contribuyente del impuesto sobre la renta a los fondos de inversión de capital extranjero por las utilidades que se obtuvieren en dicha actividad. Pero esta regla no se predicaba respecto de los dividendos, en virtud de los cuales el inversionista extranjero era contribuyente y tributaría con una tarifa del 35\% para aquellas utilidades que no habían sido gravadas en cabeza de la sociedad, y respecto a los dividendos que ya habían tributado en cabeza de la sociedad se consideraba como un ingreso no constitutivo de renta ni ganancia ocasional.

Pese a la no sujeción pasiva respecto del inversionista extranjero, la norma contemplaba una retención en la fuente practicada a los rendimientos financieros, igualándose las tarifas a las que se les practicaban a los residentes colombianos. Estas retenciones se realizaban en el momento de hacer cada pago o abono en cuenta por los diferentes sujetos, y se descontaban en el momento de realizar la declaración.

La base gravable de la retención en la fuente se practicaba sobre el rendimiento financiero obtenido en las diferentes transacciones a una tarifa del $33 \%$, sin diferenciarse el tipo de operación, ni poderse liquidar la base gravable adecuada a cada tipo de título (renta fija como los bonos, TES, CDT, o los de renta variable como las acciones) a través de algún método de determinación para depurarla, entendiéndose este como el canal para concretar la cuantía de la obligación tributaria, que por lo general es establecido por la ley tributaria determinado la reglas para aplicarle a la base que es el objeto de medición (Insignares, 2015).

Se liquidaba sobre una base bruta, a la cual no solo ya se le había practicado la retención en la fuente por el tercero -diferente a la administradora local, que realizó el pago o abono en cuenta-, sino que además solo se permitía como detracción de la base la de- 
valuación de la moneda por efectos del mercado, las pérdidas de los periodos anteriores y los costos de administración.

Lo anterior implicaba en la práctica un trato inequitativo para el inversionista de portafolio del exterior o un arbitraje regulatorio en la medida que al ser cualificado por la norma como no contribuyente, es decir como no sujeto pasivo frente al hecho generador sí era sujeto de retención en la fuente, lo que implicaba que el pago vía retención no podía considerarse en el extranjero como un impuesto directo, impidiéndole descontar dicho pago en la declaración del impuesto sobre la renta en su país de residencia ( $\operatorname{tax}$ credit) o que pudiera hacer uso de los Convenios para evitar la Doble Imposición-CDI, en el evento que Colombia (país de la fuente) tuviere uno suscrito con el país de residencia del inversionista, pues en teoría sobre él no se causaba el impuesto al no ser considerado sujeto pasivo de la obligación sustancial.

Esta circunstancia ponía al inversionista extranjero en desventaja con el inversionista residente fiscal en Colombia, puesto que este sí podía descontar o imputar el saldo presentado en la retención en la fuente en su denuncio rentístico y si se llegaba a arrojar saldo a favor imputarlo, descontarlo en las siguientes declaraciones o solicitar la devolución de los saldos.

De otra parte, el inversionista extranjero se enfrentaba con otro fenómeno, no de naturaleza tributaria sino económico que presentaba notables efectos fiscales como lo es la devaluación del peso frente al dólar -elemento que como se vio anteriormente se incluía en la base para practicar la retención en la fuente-, lo que implicó que se aumen- tara por este fenómeno en algunas ocasiones considerablemente la utilidad o el rendimiento financiero, y con ello se realizara una retención en la fuente mayor-pese a que la norma estableciera que se debía descontar el componente equivalente a la devaluación del peso-y desencadenara al final la presencia de grandes sumas de saldos a favor por esta retención practicada que, en últimas, el inversionista no podía descontar totalmente y que no podía aplicar en su impuesto sobre la renta en el país de residencia.

Lo anterior implicaba que el inversionista extranjero no fuera libre en el momento de decidir sobre su inversión en Colombia, pues se veía obligado a mantenerla en el país en el evento en que no quisiera perder esas sumas de dinero retenidas que en la mayoría de los casos eran bastante cuantiosas.

En relación con las pérdidas causadas en los fondos de inversión, la norma preveía que estas pudieran ser amortizadas sin establecer un lapso, pues la norma indicaba simplemente que se podrían hacer en los meses subsiguientes.

En materia de regulación financiera, en el año 2000 se presentó una gran modificación normativa en lo que respecta con la regulación del capital extranjero en Colombia, con la expedición del Régimen General de Inversiones de Capital del Exterior en el País y del Capital Colombiano en el Exterior, a través del Decreto 2080 de 2000. En este se indicó que toda inversión de portafolio de capital del exterior se haría por medio de un fondo de inversión de capital extranjero que tendría por único objeto realizar transacciones en el mercado público de valores, participación que solo se traducía en la compra 
y venta de acciones, bonos convertibles en acciones y demás títulos, siguiendo con ello un arbitraje para el inversionista extranjero, pues se limitaba en el mercado su actuación a solamente este tipo de operaciones, es decir, la compra y venta de títulos a través de vehículos como las carteras colectivas.

\section{Ley 1430 de 2010 - Beneficio tributario en derivados financieros}

En el 2010, se presentó una afortunada modificación a la regulación de los fondos de inversión de capital extranjero, a través del Decreto 4800, mediante el cual se estableció que la administración de estos fondos corresponde a un administrador local-sociedades comisionistas de bolsa, las sociedades fiduciarias y las sociedades administradoras de inversión-quien tendría a cargo todas las obligaciones legales que estaban en cabeza del fondo entre las que se encuentran las de orden tributario; de esta manera, el administrador practica cada mes la retención en la fuente por rendimientos financieros y se encargar de las obligaciones formales como declarar y pagar.

Sin embargo, es necesario resaltar que, pese a que la Administradora local practicaba al final del cada mes la retención en la fuente, cuando alguna entidad o persona jurídica diferente a esta hacía un pago o abono en cuenta al inversionista de portafolio del exterior, debía practicar de igual forma la retención en la fuente sobre lo pagado.

Pero quizás la más importante de las modificaciones que se realizó a la inversión de portafolio de exterior es que se le permitió al inversionista realizar todo tipo de operaciones del mercado monetario tales como realizar derivados, constituir garantías, operaciones de reporto, transferencia temporal de valores, simultáneas, etc., equiparando la participación en el mercado del inversionista extranjero al inversionista local.

Es así como ante la posibilidad que tiene el inversionista extranjero de portafolio de realizar otras operaciones y con el objeto de darle al mercado público de valor un mayor protagonismo y dinámica, se introdujo con la reforma tributaria del año 2010, el cuarto parágrafo al Artículo 36-1 del ET, en el que se creó un beneficio, que en la actualidad aún se encuentra vigente para las operaciones de derivados cuyo activo subyacente esté constituido por acciones inscritas en las Bolsa de Valores de Colombia - BVC, o para aquellos fondos de inversión colectiva que reflejen el comportamiento de las referidas acciones, que consiste en excluir estas operaciones del impuesto sobre la renta y el de ganancia ocasional.

\section{Ley 1607 de 2012 - Estructura General de la tributación de las inversiones de portafolio de inversión extranjera}

En materia de inversión extranjera concretamente a la inversión de portafolio y fondos de inversión de capital de exterior, la Ley 1607 de 2012 introdujo un conjunto de afortunadas y pertinentes normas con las cuales se buscó solucionar algunas de las asimetrías que presentaba el régimen impositivo de este tipo de inversión, así como dar mayor claridad al sistema y por qué no decirlo, permitir una dinámica al mercado de capitales, teniendo como regla general el principio de transparencia fiscal que busca dar mayor relevancia al hecho económico y al sujeto que 
efectivamente estará involucrado con este, es decir, quien percibe realmente el ingreso o asume la pérdida y lo más importe puede disponer del mismo.

Ha sido tan exitosa la reforma realizada en el año 2012, que dicho artículo no sufrió modificaciones en las reformas tributarias de los años 2014 y 2016, aunque sí se presentaron algunos efectos colaterales, como por ejemplo la exclusión del impuesto a la riqueza que fue creado con la Ley 1739 de 2014, para el inversionista extranjero de portafolio o el impuesto a los dividendos establecido en la reforma que trajo la Ley 1819 de 2016. Solo se modificó este régimen con la reciente reforma del año 2018, en la cual se redujo la tarifa de retención de los títulos de renta fija y se adicionaron algunas normas para la aplicación del principio de transparencia fiscal.

De acuerdo con lo anterior, a continuación, se analizarán los cambios relevantes que la reforma del año 2012 trajo al sistema impositivo de la inversión extranjera de portafolio.

\section{A. El inversionista extranjero de portafolio es considerado contribuyente}

En la doctrina se han establecido diferentes discusiones en relación con los sujetos pasivos que pueden presentarse en la obligación tributaria, pues se habla de contribuyente, responsable y sustituto, este último no reconocido expresamente en el ordenamiento tributario colombiano.

De acuerdo con el Artículo segundo del Estatuto Tributario, se define al contribu- yente como aquel sujeto que realiza el hecho generador de la obligación sustancial, es decir, como aquella persona natural o jurídica que realiza el supuesto fáctico que establece la ley y que asume la posición de deudora a quien se llegará a catalogar como el responsable directo del pago del tributo.

Según el doctor Marín Elizande (2015), se puede definir al contribuyente como el obligado por antonomasia a una deuda tributaria propia, siendo el único obligado al pago por realizar el hecho generador, pues los demás obligados (responsable) no realizan el hecho generador.

Por su parte, algunos consideran -como en la doctrina latinoamericana- que este se limita a los titulares de la capacidad económica, es decir que es quien se encuentra ligado al sacrificio económico destinado a contribuir al financiamiento de los gastos públicos (Valdez Acosta, 2001); a este se le identifica como el contribuyente de hecho o sujeto pasivo económico que tiene relación con el objeto imponible.

En lo que respecta a la subjetividad pasiva en el impuesto sobre la renta que deviene como consecuencia de la inversión de portafolio del exterior, se puede indicar que el concepto de contribuyente atiende única y exclusivamente al titular de la capacidad económica -sujeto pasivo económico-, es decir, al inversionista extranjero que será quien de acuerdo con la realidad económica soportará el resultado de la operación, es decir, quien tendrá una utilidad o pérdida, atendiendo con ello al principio de transparencia fiscal, pues se considera contribu- 
yente a quien se le ve afectado realmente su patrimonio por el resultado de la operación.

Luego de 20 años, la reforma que trajo la Ley 1607 de 2012, tuvo como finalidad gravar todos los ingresos del inversionista extranjero con excepción de los que corresponden a acciones o dividendos que ya fueron gravados en cabeza de la sociedad emisora, manteniendo el principio de transparencia impositiva, con lo que se retoma la calificación de contribuyente que tenía en el $90 \mathrm{al}$ inversionista extranjero.

En la exposición de motivos de la Ley 1607 de 2012 (Ministerio de Hacienda, Ministerio de Hacienda y Crédito Público), se indicó sucintamente que la modificación a la subjetividad del inversionista extranjero en las operaciones de portafolio se debía "exclusivamente con el objeto de facilitarles obtener un crédito tributario en el país de su domicilio sobre los impuestos que fueron pagados en Colombia". Esta fue una de las modificaciones más transcendentales para la inversión extranjera de portafolio, pues permitió no solo otorgar un crédito fiscal al inversionista extranjero por el impuesto sobre la renta que pagaba en el país de la fuente, sino que, además, abrió la puerta para aplicársele a la renta obtenida los convenios para evitar la doble imposición-CDI, al tener un impuesto sobre la renta definitivo a través de la retención en la fuente, mejorando así el tratamiento fiscal de la operaciones que se realicen, haciendo del mercado de capitales colombiano más atractivo y, con ello, derrotando el arbitraje regulatorio que se presentaba frente al inversionista residente en Colombia.

\section{B. En términos generales el inversionista extranjero no es titular de obligaciones formales - Excepción}

El Decreto 119 de 2017 que modificó el Decreto 1068 de 2015 establece en el Artículo 2.17.2.2.2.3 que los inversionistas de capitales del exterior deben designar un apoderado en Colombia de acuerdo con los términos de la legislación colombiana y concretamente respecto a la inversión de portafolio del exterior indica que esta se realizará a través de un administrador local (sociedades comisionistas de bolsa, sociedades fiduciarias o administradoras de inversión) quien actuará como apoderado, el cual efectuará en nombre del inversionista extranjero todas las obligaciones que deban cumplirse en el ordenamiento colombiano desde las meras formales como suministrar información a la DIAN o cualquier entidad gubernamental que lo requiera, hasta las sustanciales, como pagar el impuesto definitivo.

$\mathrm{Al}$ respecto, conviene recordar lo dispuesto en el literal h) del Artículo 572 del ET, en virtud del cual se establece que los mandatarios o apoderados generales de negocios en Colombia de residentes en el exterior, es decir, comisionistas de bolsa, la sociedad fiduciaria o admiradoras de inversión, respecto de sus representados, deben presentar sus declaraciones tributarias y cumplir con los demás deberes formales.

$\mathrm{Al}$ efecto, la exposición de motivos de la Ley 1607 de 2012 establece que en el evento que los fondos, los vehículos de inversión de portafolio del exterior o los inversionistas llegasen a presentar alguna declaración del 
impuesto sobre la renta o de ingresos y patrimonio estas no producirán efecto alguno en los términos del Artículo 594-2 del Estatuto Tributario.

Por su parte, el Artículo 18-1 del ET establece de manera expresa que será el administrador local el encargado de practicar la retención en la fuente al final de cada mes sobre las utilidades presentadas en la operación -con excepción de los dividendos gravados, pues sobres esas el agente retenedor será la sociedad pagadora del dividendo-, lo que significa que en concordancia con lo preceptuado por el Artículo 375 del referido ordenamiento, el administrador será el obligado de consignar el impuesto retenido en los plazos establecidos por el Gobierno.

Sin embargo, no debe perderse de vista que el inversionista extranjero es contribuyente del impuesto sobre la renta, lo que implica que debe cumplir por intermedio de su representante todas las obligaciones sustanciales y formales que determina el ordenamiento tributario. Lo anterior, conlleva analizar la subjetividad pasiva de la administradora o representante del inversionista extranjero ante la obligación tributaria que nace por su rol.

El punto de partida en relación con los deberes formales de los contribuyentes es el Artículo 571 del ET, en virtud del cual se establece de manera clara la obligación por parte de los contribuyentes y responsables directos del tributo, como sucede con el administrador local respecto del inversionista extranjero de portafolio, de cumplir con los deberes formales, los cuales - tal como se ha visto, en el caso del inversionista extranjeroserá a través de su representante.
Al respecto, el Artículo 572-1 del ET, modificado por la Ley 1819 de 2016, reconoce una responsabilidad solidaria entre el inversionista extranjero y el mandatario especial como en este caso lo sería el administrador local por el incumplimiento de las obligaciones sustanciales y formales del inversionista que le hayan sido encargadas; de esta manera, el administrador responderá, entre otras, por el pago del impuesto, las sanciones de extemporaneidad, la sanción por mora, de los mayores valores determinados por la Administración Tributaria, entre otros (Concepto DIAN $\left.n^{\circ} .18752,2016\right)$.

De acuerdo con lo anterior, al analizar la responsabilidad del administrador local se podría indicar que su rol respecto a la obligación jurídico-tributaria puede ser considerado como un sustituto, figura que no es reconocida por el ordenamiento tributario colombiano, pero que sí puede configurarse en este caso si se tiene en cuenta que i) su subjetividad deviene de la ley ; ii) la administradora está obligada a la satisfacción de la obligación originada por el inversionista al generarse la utilidad en la operación; iii) frente a la administración tributaria la comisionista de bolsa, la sociedad fiduciaria o de inversión queda como único sujeto vinculado frente a la Administración; iv) la administradora puede repetir contra el inversionista, y v) la administradora está sujeta a las obligaciones formales como presentar la declaración, presentar la información que solicite la DIAN, tal como lo indica el parágrafo segundo del Artículo 18-1 del ET.

Se ha indicado por un sector de la doctrina que el término responsable que utiliza el ordenamiento tributario colombiano no se encuentra bien concebido, si se tiene en cuenta 
que este sujeto, por lo general, solo responde por la deuda tributaria sustancial, es decir, la obligación material de pago, mas no de los deberes formales (Marín Erizalde, 2015), diferencia tangencial con la sustitución. Sin embargo, para efectos prácticos entenderemos a la administradora local como responsable pese a asimilarse más al sustituto.

Por último, conviene llamar la atención que, como toda regla general, se presenta una excepción en relación con el hecho de que el inversionista extranjero no es titular de los deberes formales y sucede cuando se enajena más del 10\% de las acciones inscritas en la bolsa de valores de las acciones en circulación de la respectiva sociedad durante el mismo año gravable, pues en ese evento será el inversionista extranjero a nombre propio quien presente la declaración de renta, por la referida operación, tal como lo indica el numeral 5 del Artículo 18-1 del ET.

\section{La retención en la fuente es el impuesto definitivo y es practicada por la Administrador Local}

El mecanismo de la retención en la fuente se implementó en Colombia a través del Decreto 1651 de 1961 en el cual se facultó al Gobierno Nacional para establecer este mecanismo con el objeto de facilitar, acelerar y asegurar el recaudo del impuesto sobre la renta y complementarios. De esta manera, la retención en la fuente permite facilitar el trabajo de la Administración fiscal y tiene por objeto no solo permitirle al estado tener flujo de recursos, sino bajar los costos del recaudo ayudando a que el impuesto se recaude, en lo posible, en el periodo en el que se causa (Artículo 367 de ET) (Piza, Insignares y Sarmiento Pérez, 2010).
La obligación de retener es independiente y autónoma de la obligación sustancial que nace cuando se cumple el hecho generador, es decir que la obligación que establece el numeral segundo del Artículo 18-1 al administrador local de retener cada mes el impuesto sobre la renta de las utilidades percibidas en cada operación es completamente diferente a la obligación que como contribuyente presenta el inversionista como sujeto pasivo económico.

Al establecer la Ley 1607 de 2012, que el Administrador local será el que practique la retención en la fuente al final de cada mes y determinar una base gravable para cada operación, permite que se eliminen las retenciones en exceso y con ello -tal como lo expresa claramente la norma- impide que cualquier otra entidad diferente a la Administradora que realice pagos, directa o indirectamente, a los inversionistas de capital del exterior de portafolio, efectúe retención alguna, evitando que se practique una doble retención por un mismo ingreso. Esta circunstancia quedó expresamente establecida en el numeral tercero del Artículo 18-1 del ET, que fue modificado en la reciente reforma del año 2018.

Impedir que cualquier entidad diferente a la Administradora local practique la retención en la fuente cuando se realice el pago o abono en cuenta, hace de este mecanismo anticipado de recaudo un mecanismo sui generis y especial, pues no atiende a la regla general que es precisamente que la retención se practica por quien realiza el pago o el abono en cuenta (lo primero que suceda), sino que la misma se practica al cierre del mes y no por la entidad que realiza el pago sino por un tercero que en este caso es la administradora. 
De esta manera se logró atacar una de las falencias que presentaba la normativa anterior, pues al practicarse diferentes retenciones en la fuente por cada sujeto que realizaba el pago o abono en cuenta, producía una cadena de retenciones que generaba para el inversionista un alto costo de índole financiero. Además, como ya se expuso, al presentarse esas sumas excesivas de retención en la fuente y al no ser contribuyente obligada al inversionista a mantener su inversión en Colombia.

Conviene precisar que el Administrador local está obligado desde el punto de vista material que al aplicar la retención en la fuente se practiquen las mismas reglas de determinación del impuesto, lo que implica que se deben utilizar las normas para caracterizar todos los elementos de la obligación sustancial (Marín Erizalde, 2015) más aún si se tiene en cuenta que, en este caso, la retención en la fuente es el impuesto sobre la renta definitivo del inversionista extranjero de portafolio. Así, el Administrador local debe examinar la operación y determinar los elementos esenciales del respectivo impuesto liquidando el que sería el tributo definitivo a pagar.

Para dicho efecto, el numeral 4 del Artículo 18-1 establece la base gravable sobre la cual se debe practicar la retención en la fuente que presenta una tarifa general del $14 \%$, siempre que el inversionista del exterior no se encuentre domiciliado en una jurisdicción calificada por Colombia como paraíso fiscal, de baja imposición o no cooperante, pues en dicho evento se deberá aplicar una tarifa del $25 \%$.
Como se ha expuesto, por regla general el agente retenedor en las operaciones de portafolio de inversión de capital extranjero es la Administradora local, que pueden ser la sociedades comisionista de bolsa, sociedades fiduciarias o administradoras de inversión; sin embargo, esta regla tiene una excepción y se presenta cuando la retención se practica sobre los dividendos que tributan en cabeza de la sociedad, la cual debe ser practicada por la sociedad pagadora del dividendo en el momento de realizarse el pago o abono en cuenta.

Se ha indicado que una de las falencias del sistema de retención en la fuente general que presenta el ordenamiento tributario colombiano es que el pago no se imputa a la cuenta corriente del beneficiario con la declaración que realiza el agente retenedor (Marín Elizalde, 2015), en razón a que no puede identificarse a quien se practica el anticipo de impuesto, situación que no cambia en la retención en la fuente practicada al inversionista, pues la sociedad comisionista de bolsa, sociedad fiduciaria o administradora de inversión extranjero, recoge en una sola declaración la retención practicada a todos sus inversores y solo se podrá discriminar el pago del impuesto cuando la administración solicité la información respectiva a la Administradora local.

Sin embargo, no debe perderse de vista que de conformidad con el Artículo 381 del ET, se impone la obligación a la administradora de expedir anualmente el certificado de retención en la fuente en el cual se debe identificar, entre otros, al inversionista extranjero de portafolio (persona natural o 
jurídica extranjera) a quien se le practicó la retención, así como el monto total, concepto del pago sujeto a retención y de la retención como la cuantía de esta.

De acuerdo con todo lo anterior, al ser reconocido el inversionista de portafolio del exterior como contribuyente del impuesto sobre la renta por la norma colombiana y al convertirse la retención en la fuente en el impuesto definitivo, la certificación expedida por la administradora del portafolio se convertirá en el documento soporte sobre el cual el inversionista podrá en su país de residencia aplicar o descontar el crédito fiscal por el impuesto pagado en Colombia.

Por último, es necesario hacer la precisión que por regla general el Administrador local deberá practicar la retención en la fuente para efectos de establecer el impuesto definitivo del inversionista; sin embargo, toda regla trae su excepción, tal como se presenta cuando las utilidades superan el límite establecido en el Artículo 36-1 del ET, es decir, cuando la enajenación de acciones supera el diez por ciento (10\%) de las acciones en circulación de la respectiva sociedad, durante un mismo año gravable, pues en este evento no se realiza la retención en la fuente sino que se presenta por parte del inversionista extranjero de portafolio la declaración del impuesto sobre la renta, gravándose dicha utilidad a una tarifa del $33 \%$, tal como lo dispone el Artículo primero del Decreto 2108 de 2013.

\section{La Base gravable es el resultado neto de cada operación}

Acatando el mandato constitucional establecido en el Artículo 338 de la Carta Polí- tica de 1991, la Ley 1607 de 2012 establece de manera expresa uno de los elementos esenciales del tributo, como lo es la base gravable sobre la cual se aplica al final de cada mes la tarifa de la retención en la fuente al inversionista.

Esta base gravable se encuentra liquidada sobre la utilidad obtenida por el inversionista durante el mismo mes y deberá atender las reglas que para cada una de las operaciones -instrumentos de derivados financieros, títulos con rendimientos, transferencia temporal de valores, repos, simultáneas.

La base gravable presenta una evidente diferencia con la establecida en la Ley 223 de 1995: tiene un método de determinación que busca estimar directamente varios datos que reflejan la capacidad económica del inversionista, llegando a la utilidad de las operaciones a través de un conjunto de reglas establecidas de manera lógica, estudiada y acertada y cuyo resultado en últimas será determinar de manera real la utilidad obtenida por el inversionista del exterior, es decir, a cada una de las operaciones realizadas por el inversionista se le tienen en cuenta no solo las inclusiones como los rendimientos obtenidos en la operación sino también las exclusiones, como por ejemplo las pérdidas generadas o los gastos de administración, para así aplicar la tarifa.

De esta manera, se observa que la base gravable reza con el principio de progresividad desarrollado a través del análisis de la capacidad contributiva del contribuyente, en este caso el inversionista, definido como "la posibilidad económica que tiene una persona de tributar, o sea, la idoneidad subjetiva, no teórica sino real, en cuanto depende 
de la fuerza económica del sujeto, para ser llamado a cumplir con el deber de pagar tributos" (Sentencia C-173, 2010), lo que se evidencia con la posibilidad de detraer de los rendimientos las pérdidas que se puedan presentar en cada operación y los gastos de administración.

En este punto conviene definir qué se entiende por utilidad; pues bien, de acuerdo con la jurisprudencia del Consejo de Estado, se ha indicado que este término el legislador lo asimiló al de renta líquida, esto es, "la que resulta de la diferencia entre ingresos menos costos y deducciones, y que, salvo excepciones legales, es renta gravable" (Sentencia Exp. 21883, 2017). De esta manera, la utilidad se puede entender como un sinónimo de la renta líquida a la cual se aplica la alícuota o tarifa respectiva, lo que lleva a concluir que la base que establece la modificación del Artículo 18-1 del ET, es una base depurada -no tan compleja como la de un residente fiscal-, que será la que resulte de aplicar los ingresos (rendimientos presentados en las diferentes operaciones) menos las pérdidas y la depreciación de la moneda.

De esta manera, la utilidad en el impuesto sobre la renta aplicable al inversionista extranjero de portafolio será la que se determine en cada operación realizada, es decir, que la utilidad es definida como la diferencia entre los resultados determinados con base en la naturaleza del renta obtenida (Jiménez Mejía, Higuita Naranjo y otros, 2012), es decir, se liquidará de acuerdo con cada tipo de operación (instrumentos de derivados, transferencia temporal de valores, operaciones de reporto, simultáneas, negociación de títulos en general).
Así, al depurarse individualmente cada operación, significa que en materia fiscal cada operación es independiente, lo que conlleva que para la liquidación del impuesto se deba realizar una cedulación, diferente a la base establecida antes de la reforma del 2012, que incluía todas las operaciones sin importar su naturaleza.

La cedulación establecida en el Artículo 18-1 del ET, modificado a través del Artículo 125 de la Ley 1607 de 2012, indica cuatro tipos: la primera relacionada con los instrumentos financieros derivados; la segunda, relacionada con los títulos con rendimientos y/o descuentos; la tercera, para las operaciones de liquidez, como las operaciones de reporto, simultáneas y transferencia temporal de valores, y la cuarta, que es la residual establecida para las otras operaciones que no fueron descritas expresamente en la norma.

Luego de depurar las diferentes bases gravables de acuerdo con el tipo de operación realizada al final del ejercicio, es decir, cada mes, la Administradora local deberá sumar todas las bases liquidadas y detraer de estas los gastos de administración para así obtener la utilidad real que el inversionista extranjero ha obtenido en las operaciones de portafolio y aplicarle la correspondiente tarifa de retención.

De esta manera, la base gravable de las principales operaciones de portafolio se depurará de la siguiente manera:

a)Instrumentos derivados. Tal como se indicó en el capítulo anterior, los instrumentos financieros conocidos como derivados son contratos cuyo valor dependerá del subyacente, entendido 
como el activo o el bien cuyo valor depende de la variación en el mercado de valores y que puede representar para una entidad un activo y para otra a la vez como un pasivo.

La base gravable para calcular la retención en la fuente mensual será el resultado neto de los pagos o abonos en cuenta hechos, a favor y en contra (pérdidas), los cuales pueden ser directa o indirectamente abonados al inversionista, lo cual se dará en razón a la liquidación y cumplimiento de todos los instrumentos financieros derivados que se hayan vencido o liquidado en el mes, pudiendo ser disminuida la base en el evento que se presenten pérdidas, pues no debe perderse de vista que en últimas lo que se busca es obtener la utilidad.

En el caso de las permutas financieras o swaps, los resultados que se obtengan antes del vencimiento que correspondan a la liquidación de cada uno de los flujos del respectivo instrumento, hacen parte de la base gravable del periodo en el que se pagan o abonan en cuenta.

b)Títulos. Frente a los títulos, se puede decir que la reforma del 2012 equiparó en lo que respecta a la depuración de la base gravable del impuesto al inversionista extranjero de portafolio con los inversionistas en bolsa locales, puesto que se determina de manera expresa que tanto para las posiciones en portafolio como para la enajenación de títulos, la base partirá de los rendimientos que se determinen de acuerdo con la normativa vigente para liquidar la retención en la fuente de títulos de renta fija para residentes, es decir, lo que dispone el Decreto 700 de 1997.

c) Transferencia temporal de valores, repos y simultáneas. Estas operaciones han sido definidas en el capítulo anterior, y se puede indicar que el común denominador de estas se encuentra en su objeto, el cual no es otro que encontrar liquidez de recursos.

La base gravable se depura por el valor neto que resulte de los pagos girados o los abonos hechos (directa o indirectamente), los cuales pueden ser a favor o en contra del inversionista. Conviene resaltar que esta depuración o liquidación de la base se realizará al final de la operación en la cual se deberá tener en cuenta, tal como sucede en las demás operaciones las pérdidas que se presenten contra las utilidades obtenidas.

Algunos expertos, como el profesor Jairo Higuita, consideran que en este caso son aplicables los artículos 2.36.3.1.4 y 2.36.3.1.17 del Decreto 2555 de 2010, en razón a que de acuerdo con estos preceptos para todos los efectos legales se entiende que los diferentes actos de transferencia de valores o dinero, así como la constitución y liberación de garantías, asociadas a una operación de reporto o repo, simultánea o de transferencia temporal de valores, corresponden en cada caso a una sola operación entre las partes contratantes.

d) Base residual. Con el objeto de prever la base gravable de futuras operacio- 
nes, puesto que el mercado de valores es excesivamente dinámico y la evolución de este permite la creación de nuevas operaciones, se establece una base para las demás operaciones que no se cualifiquen como las anteriormente descritas; en este evento, la base gravable será por el valor neto que resulte de los pagos o abonos en cuenta que se hagan directa o indirectamente al inversionista, a favor o en contra, en desarrollo de la operación.

Así mismo, se presentará una base gravable especial cuando las utilidades superen el límite establecido en el inciso segundo del Artículo 36-1 del ET, pues en dicho evento la base se liquidará vía declaración de renta, que, como ya se ha expuesto, será presentada por el inversionista de portafolio extranjero y se le aplicará la tarifa del $33 \%$.

\section{E. Tarifa del $14 \%$ aplicable a las operaciones de portafolio del inversionista, con algunas excepciones}

La tarifa establecida en la Ley 1607 de 2012, para los rendimientos respecto de las inversiones de portafolio del exterior es una tarifa general del 14\%, la cual en un principio no era la que proponía el Ejecutivo al discutir la reforma fiscal, pues en la exposición de motivos de la reforma tributaria, se indicó:

(...) se establece el $25 \%$ como tarifa general del impuesto a cargo de los fondos o vehículos de inversión de portafolio del exterior o inversionistas, que es la tarifa correspondiente al régimen ordinario del impuesto de renta sobre personas jurídicas. No obstante, se fija por ley una tarifa especial o extraor- dinaria del 14\% que podrá aplicarse cuando el gobierno nacional lo determine por decreto, en razón a la existencia de condiciones generales de la economía que hagan favorable la atracción de la inversión extranjera de portafolio (Congreso de la República, Gaceta, 2015).

De esta manera, la tarifa del 14\% se había establecido en principio como una tarifa especial cuya aplicación se determinaría el Gobierno; sin embargo, esta fue la tarifa general para las operaciones, teniendo como única explicación para su reducción hacer atractivo y competitivo el mercado de capitales colombiano e incentivarlo ante la inversión extranjera respecto de los mercados de la región.

La tarifa del 14\% presenta algunas excepciones reguladas en el Artículo 18-1 del ET. Entre estas excepciones se encuentran cuando el inversionista reside en algunas de las jurisdicciones denominadas por la reciente reforma tributaria como no cooperantes, de baja o nula imposición y regímenes tributarios preferenciales, pues en este evento la tarifa de retención es del $25 \%$. Sobre estas jurisdicciones conviene destacar que son clasificadas cada año por el Gobierno Nacional mediante decreto; sin embargo, desde el 2014 no se ha modificado dicha lista contenida en el Decreto 1966 de octubre 7 de 2014, el cual fue modificado con el Decreto 2095 de octubre 21 de 2014 y luego se incorporó en los artículos 1.2.2.5.1. hasta 1.2.2.5.3 del Decreto Único Tributario 1625 de octubre 11 de 2016.

Otra excepción a la aplicación de la tarifa general es cuando corresponda a dividendos gravados, cuya tarifa a practicar será igual a 
la tarifa antes indicada, es decir, del 25\%,y, en este caso, la sociedad pagadora del dividendo será la que realice la retención.

Al efecto, y ante la reforma del 2016, que más adelante se analizará, el Decreto 640 de 2018 establece el procedimiento para practicar la retención en la fuente por concepto de dividendos, para el inversionista de portafolio de inversión. Sobre la tarifa a aplicar a los dividendos, la Ley de Financiamiento trajo algunos cambios que más adelante se abordarán.

Otra excepción a la tarifa general se encuentra la establecida para los títulos públicos o privados de renta fija a los que en la reciente Ley de Financiamiento se le disminuyó la tarifa al $5 \%$.

Y la última excepción a la aplicación de la tarifa del $14 \%$ se presenta cuando las utilidades superen el $10 \%$ de las acciones en circulación, en cuyo caso se debe presentar declaración de renta y aplicar una tarifa del $33 \%$.

En este punto resulta necesario preguntar: ¿puede considerarse dicha alícuota competitiva frente a los mercados de la región (Perú, Argentina, Brasil y México)? De acuerdo con un estudio comparado realizado en junio del 2017, por el Instituto Colombiano de Derecho Tributario - ICDT denominado "Tributación de los mercados de capitales en América Latina", se evidenció que entre los países que presentan una tributación más benevolente frente a la inversión extranjera en el mercado de capitales es Brasil, en el cual los dividendos se encuentran exentos así el inversionista se encuentre domiciliado en un paraíso fiscal, las ganancias de capital siempre que se trate de enajenación de valores transados en bolsa y pagos a un no residente corren la misma suerte, es decir, son exentas. En la tabla 1 se presenta un comparativo en el cual se indican las tarifas de tributación en el mercado de capitales de algunos países de la región.

De acuerdo con la información anterior, se observa que entre los países con tasas o tarifas más competitivas en la región se encuentra Brasil, en el cual la mayoría de las operaciones están exentas de impuestos directos, cuando son realizadas por un inversionista extranjero en el mercado de valores, seguido por Perú, donde se observa que son igualmente exentos los rendimientos y las ganancias de capital en el mercado de valores, así como las utilidades presentadas en los instrumentos financieros de derivados.

Respecto a México, se evidencia que, pese a que no se encuentran exentas la totalidad de las operaciones de los inversionistas extranjeros en el mercado de valores o capitales, los ingresos por concepto de dividendos y ganancias de capital tienen una tarifa más competitiva que la colombiana, pues es del $10 \%$ contra un $14 \%$ (diferentes a dividendos), aunque en materia de derivados financieros sí se observa una tarifa que oscila entre el 25\% hasta el $40 \%$ dependiendo el tipo de renta que represente, lo que hace que, en lo que respecta a este tipo de operaciones, resulte más competitivo el mercado colombiano.

\section{F. El inversionista extranjero puede aplicar los CDI - Convenios para evitar la doble imposición}

Como ya se ha expuesto, con la reforma del año 2012 el inversionista extranjero es 


\section{Tabla 1.}

Tarifas de retención en la fuente. Dividendos y rendimientos financieros. Países de la región

\begin{tabular}{|c|c|c|}
\hline País & Concepto & Tarifa \\
\hline México & $\begin{array}{l}\text { Dividendos } \\
\text { Base: Valor bruto - utilidades generadas a partir del } 2014 \\
\text { Ganancias de capital: } \\
\text { Transferencia de participaciones de fondos de renta variable. } \\
\text { Venta de acciones públicas registradas en el Sistema Internacional de Valores. } \\
\text { Derivados } \\
\text { Rentas que representan acciones } \\
\text { Rentas que representan deuda }\end{array}$ & $\begin{array}{l}10 \% \text { pago es a residente } \\
\text { o no residente } \\
10 \% \\
10 \% \\
25 \% \\
4,9 \% \text { al } 40 \%\end{array}$ \\
\hline Perú & $\begin{array}{l}\text { Dividendos } \\
\text { No residentes } \\
\text { Ganancia de capital } \\
\text { Rendimientos y ganancias en general mercado de valores. } \\
\text { Por venta de activos. No residente (natural o jurídica)- venta de valores ins- } \\
\text { critos en el Registro Público de Valores } \\
\text { Derivados }\end{array}$ & $\begin{array}{l}8 \% \text { años } 2017 \text { y } 2018 \\
9,3 \% \text { en adelante } \\
\text { Exonerado } \\
5 \% \\
\text { Exonerado }\end{array}$ \\
\hline Brasil & $\begin{array}{l}\text { Dividendos } \\
\text { Pagados a no residentes - incluso domiciliado en paraíso fiscal } \\
\text { Ganancia de capital } \\
\text { Pagadas a no residentes siempre que enajenación sea en mercado de valores } \\
\text { Derivados } \\
\text { Tranzados en mercado de valores }\end{array}$ & $\begin{array}{l}\text { Exento } \\
\text { Exento }\end{array}$ \\
\hline Argentina & $\begin{array}{l}\text { Dividendos } \\
\text { Impuesto de compensación } \\
\text { Ganancia de capital } \\
\text { Derivados } \\
\text { Pago a favor de un no residente }\end{array}$ & Exentos \\
\hline
\end{tabular}

Fuente: Elaboración propia con datos del Instituto Colombiano de Derecho Tributario (2018).

considerado contribuyente, noción que de acuerdo con la exposición de motivos de la Ley 1607 de 2012, buscó para el inversionista de portafolio "facilitarles obtener un crédito tributario en el país de su domicilio sobre los impuestos que fueron pagados en Colombia”. Esta medida ayuda a que no se presente una doble imposición para el inversionista sobre la misma renta.

En este punto, conviene recordar qué se entiende por doble imposición: al respecto, la OCDE trae un concepto que ayuda a entender este fenómeno, pues la define "como la 
aplicación de impuestos similares, en dos (o más) Estados, a un mismo contribuyente respecto de la misma materia imponible y por el mismo período de tiempo" (OCDE, 2014). De acuerdo con la anterior definición, la doble imposición se presenta cuando se cumplen las siguientes características: i) es respecto de un mismo contribuyente; ii) recae sobre un mismo hecho imponible; iii) se grava en el mismo periodo y iv) se gravan los ingresos en dos o más Estados.

La doble tributación parte en primera medida de que se grave a un mismo sujeto pasivo, denominado contribuyente, en dos jurisdicciones impositivas diferentes (país de la fuente y en el de residencia), lo que significa que, a la luz de la reforma del año 2012 , respecto del inversionista extranjero de portafolio se configuraría la doble imposición en el evento en que, sobre los ingresos percibidos en las operaciones de portafolio, también se le grave en su país de residencia.

Lo anterior no significa que la doble tributación no se presentara respecto de los ingresos obtenidos por el inversionista extranjero durante los años anteriores, ya que de manera fáctica se estructuraba la doble imposición; sin embargo, a este fenómeno no se le podía dar tal connotación pues en Colombia el inversionista extranjero no era considerado contribuyente y, por ende, la retención en la fuente que se le practicaba no tenía la vocación normativa de impuesto y por lo tanto, al no tener la vocación de impuesto definitivo, no se le permitía en el Estado de la residencia aplicar dicho pago como crédito fiscal ni aplicar un CDI.

Considerar contribuyente al inversionista extranjero de portafolio fue una de los más importantes modificaciones que presentó la Ley 1607 de 2012, pues al tener tal calificación, el impuesto definitivo que en este caso es la retención en la fuente practicada por la Administradora local, se le permite reconocer que eventualmente sobre esos ingresos se podría presentar una doble imposición, y así, en el evento de que su país de residencia tenga suscrito un CDI con Colombia, se abra la posibilidad de aplicarlo para neutralizar dicho efecto.

En la actualidad, Colombia tiene suscritos 15 Convenios para Evitar la Doble Imposición, los cuales ya han sido ratificados o incorporados a la legislación interna y se están negociando 7 más con los países de Alemania, Japón, Bélgica, Países Bajos, Estados Unidos, Panamá y Reino Unido. Además, no puede olvidarse las normas de la Comunidad Andina en materia del impuesto sobre la renta y patrimonio establecidas en la Decisión no .578 de 2004.

En la tabla 2 se hace una reseña de los diferentes CDIS.

Los convenios suscritos con Alemania (1970), Italia (1981), Argentina (1970), Panamá y Brasil (1993), tienen como regla general que son aplicables únicamente a favor de sociedades marítimas o aéreas, los cuales no atienden al modelo de la OECD.

Los CDI suscritos por Colombia, atienden al modelo OCDE (este modelo de convenio se ha utilizado como documento marco en las negociaciones entre países miembros y no miembros e incluso entre países no miembros), modelo que ha sido creado con el fin de unificar los problemas que se presentan sobre la doble imposición y de parametrizar 
Tabla 2.

CDI suscritos por Colombia a año 2018

\begin{tabular}{|c|c|c|c|}
\hline País & Entrada en vigencia & \begin{tabular}{|c|} 
Ley que lo incorpora \\
la Derecho interno
\end{tabular} & $\begin{array}{r}\text { Sentencia de estudio } \\
\text { de constitucionalidad }\end{array}$ \\
\hline España & 23 de octubre de 2008 & Ley 1082 de 2006 & C-838 de 2008 \\
\hline Chile & 22 de diciembre de 2009 & Ley 1261 de 2009 & C-577 de 2009 \\
\hline Suiza & $1^{\circ}$ de enero de 2012 & Ley 1344 de 2009 & C-460 de 2010 \\
\hline Canadá & 12 de junio de 2012 & Ley 1459 de 2011 & C-292 de 2012 \\
\hline México & $1^{\circ}$ de agosto de 2013 & Ley 1568 de 2012 & C-221 de 2013 \\
\hline Corea del Sur & 3 de julio de 2014 & Ley 1667 de 2013 & C-260 de 2014 \\
\hline Portugal & 30 de enero de 2015 & Ley 1692 de 2013 & C-667 de 2014 \\
\hline India & 7 de julio de 2014 & Ley 1668 de 2013 & C-238 de 2013 \\
\hline Republica Checa & Mayo de 2015 & Ley 1690 de 2013 & C-049 de 2015 \\
\hline Francia & Suscrito el 25 de junio de 2015 & & \\
\hline
\end{tabular}

Fuente: DIAN (2018).

las soluciones o neutralizar los efectos de dicho fenómeno.

Estos convenios circunscriben su aplicación única y exclusivamente respecto de aquellos tributos que tienen por objeto gravar los ingresos de un residente de un Estado contratante a título del impuesto sobre la renta y patrimonio o aquellos que le sean de naturaleza idéntica o análoga como, por ejemplo, aquellos impuestos sobre las ganancias derivadas de la enajenación de la propiedad mobiliaria o inmobiliaria, los impuestos sobre los importes totales de los sueldos o salarios pagados por las empresas -Artículo primero (Economico y OCDE, 2010).

Para aplicar el inversionista extranjero de portafolio los CDI, es necesario estudiar la subjetividad del contribuyente respecto al convenio; para el efecto es necesario tener presente que se deben cumplir dos presupuestos a la luz del modelo de convenio OCDE: i) ser considerado residente fiscal en el Estado con el que se tiene suscrito el convenio y ii) que dicha persona sea el beneficiario efectivo de la renta que se pretende gravar.
La expresión beneficiario efectivo puede resumirse como el sujeto que percibe el ingreso y que tiene toda la vocación para disponer del mismo (no necesariamente tiene que ser el titular de la acción o de la inversión). Vogel (citado por Vega Borrero, 2003) expone que en el concepto de beneficiario efectivo tiene más importancia quien se beneficia materialmente de ese rendimiento, con independencia de quién es el titular, es decir, que lo que cualifica al preceptor como beneficiario efectivo es la libertad para disponer del rendimiento percibido.

Es así como a la luz de los CDI, el sujeto pasivo de la obligación sustancial no solo se limita a la concepción de residente, lo que implica que si el inversionista de portafolio actúa a través de un intermediario quien es considerado residente de un Estado con quien se tiene suscrito CDI y no es el beneficiario efectivo (mandatario, fiduciario o administrador), no se le aplicarán los efectos del convenio, pues no podría considerársele como quien percibe realmente el ingreso. 
En la práctica, resulta compleja la aplicación de los CDI, respecto del inversionista extranjero de portafolio cuando se presentan operaciones en la cuales se involucran más de dos Estados. Tal es el caso de las operaciones que implican triangulaciones en las que puede resultar difícil la identificación del beneficiario efectivo, de la jurisdicción en la que se percibe el ingreso y del porcentaje del ingreso, así como la tarifa al que se le puede aplicar el CDI.

Para aplicar los CDI, es necesario tener presente el tipo de renta a la cual se le aplicaría el convenio, y para ello resulta importante conocer la clase de títulos o valores negociados en el mercado y las operaciones realizadas.

La Ley 964 de 2005 define en el Artículo segundo el concepto de valor como todo derecho de naturaleza negociable que haga parte de una emisión, cuando tenga por objeto o efecto la captación de recursos del público, entre los que se enlistan de manera enunciativa las acciones, bonos, papeles comerciales, certificados de depósito de mercancías, cualquier título representativo de capital de riesgo, cédulas hipotecarias y cualquier título de deuda pública y los derivados.

En este punto, es necesario aclarar que de acuerdo con la normativa tributaria colombiana, concretamente con el parágrafo primero del Artículo 20-1 del ET, se excluye de las normas de establecimiento permanente al inversionista de capital extranjero de portafolio, es decir que esta no podría configurarse siempre y cuando este realice sus actividades en el país a través de un corredor o cualquier agente independiente y que dicho administrador lo haga dentro del giro ordinario de sus negocios. Lo anterior significa que, para efectos del estudio de los CDI, respecto a las rentas que obtiene el inversionista de portafolio del exterior, no se aplicará en ningún caso el Artículo 5 de los CDI, que por regla general es relativo a las normas de establecimiento permanente.

De otra parte, no puede perderse de vista que en el ámbito de la norma andina también se puede aplicar al inversionista extranjero de portafolio lo dispuesto en la Decisión 578 de 2004, "Por medio de la cual se actualizan las normas referentes a evitar la doble tributación entre los países miembros, con el fin de fomentar los intercambios entre los países miembros, atraer la inversión extranjera y prevenir la evasión fiscal".

\section{- Artículo 10 de los CDI-Dividendos}

Se entiende por dividendo cualquier beneficio económico que sea suministrado a los accionistas cuya característica especial radica en que son un retorno sobre el capital (Rohatgi, 2008); sin embargo, el Artículo 10 de los Convenios para evitar la Doble Imposición trae su propia definición entendida como la renta "obtenida de las acciones, de las acciones o bonos de disfrute, de las participaciones mineras, de las partes de fundador u otros derechos, excepto los de crédito, que permitan participar en los beneficios, así como las rentas de otras participaciones sociales sujetas al mismo régimen fiscal que las rentas de las acciones por la legislación del Estado de residencia de la sociedad que hace la distribución".

La anterior definición tiene un alto componente casuístico, si se tiene en cuenta que, por la diversidad de legislaciones de los 
países miembros de la OCDE, no era posible ofrecer una definición completa y exhaustiva del concepto de dividendo, lo que implicó que en el modelo la definición del artículo se limite a mencionar los ejemplos que figuran en la mayor parte de estas legislaciones y cuyo tratamiento tributario se da bajo la connotación de dividendo.

La precisión que es necesario hacer deriva de que, de acuerdo con la clase y naturaleza del valor negociable en el mercado público de valores, los dividendos que para este trabajo interesan son los obtenidos en sociedades anónimas, puesto que son las únicas a las que en Colombia se les permite negociar en este tipo de mercado.

En este precepto no se establece una norma que otorgue la potestad de gravar el dividendo exclusivamente al Estado contratante de la residencia o al de la fuente, pues deja en libertad de estos su imposición. Autores como Castro Arango (2016) indican que este artículo establece para los dividendos una norma incompleta o de acumulación de potestades impositivas, pues se puede convenir que se grave exclusivamente en la fuente, en la residencia o una tributación compartida con una limitación si es del caso del gravamen en el país de residencia .

Sin embargo, esta regla puede no establecerse; tal es el caso del Convenio para Evitar la Doble Imposición suscrito entre Colombia y México incorporado al ordenamiento interno a través de la Ley 1568 de 2012, en el cual se establece exclusividad en la imposición de los dividendos al país de la residencia al señalar que "los dividendos pagados por una sociedad residente de un Estado Contratante a un residente del otro Estado Contratante sólo pueden someterse a imposición en este otro Estado".

Es por lo anterior que en este artículo se establecen unas reglas que pueden acatarse en el evento que el Estado contratante de la sociedad que paga los dividendos (de la fuente) grave este tipo de ingreso, las cuales buscan poner un techo o límite en la tarifa del tributo. Así, el impuesto exigido no podrá exceder:

a) Del 5\% del importe bruto de los dividendos si el beneficiario efectivo es una sociedad que posea directamente al menos el 25\% del capital de la sociedad que paga los dividendos;

b) Del 15\% del importe bruto de los dividendos en los demás casos.

De esta manera, en el evento que el Estado contratante de la sociedad pagadora del dividendo Colombia grave - como en efecto sucede- el dividendo, la tarifa aplicable no puede superar del 5\% cuando la sociedad beneficiaria posea el $25 \%$ del capital de la sociedad pagadora (es decir vinculada) y del $15 \%$ en el resto de los casos.

Esta condición no se exige respecto de un periodo determinado, es decir, la norma no establece que la vinculación entre la sociedad pagadora del dividendo y el inversionista -para este caso-, se haya presentado con anterioridad al momento en que se causa el tributo, puesto que dicha circunstancia se analiza es en el momento en que nace la sujeción al impuesto (economico y OCDE ,2010). Todo lo anterior, siempre que no se haya utilizado la figura con un fin abusivo, es decir que se haya estructurado la vinculación con el objeto de minorizar el impuesto, pues en este caso no será posible aplicar este artículo. 
La anterior disposición resulta más favorable que la norma colombiana, si se tiene en cuenta que el Artículo 18-1 del ET establece una tarifa del $25 \%$ siempre que corresponda a dividendos gravados y que el inversionista no se encuentre en una jurisdicción de baja imposición o no cooperante en su defecto y si el dividendo es gravado de acuerdo con el parágrafo segundo del Artículo 49, es decir, el exceso de utilidad máxima para distribuir como ingreso no constitutivo de renta ni ganancia ocasional, se le deberá adicional un $7,5 \%$, tal como lo dispone la reciente reforma tributaria del 2018.

Sin embargo, de acuerdo con la DIAN (Concepto $\mathrm{n}^{\circ}$. 24422, 2018), se determinó que la tarifa especial del $5 \%$ para practicar a los dividendos que no tributan en cabeza de la sociedad, establecida en el Artículo 7 de la Ley 1819 de 2016, por medio del cual se modificó el Artículo 245 del ET, es aplicable para las inversiones de capital del exterior, estableciéndose así una tarifa efectiva del $28,15 \%$. Es tarifa fue modificada con la reciente Ley de Financiamiento, la cual aumentó al 7,5\%.

Ahora bien, cuando se distribuyen como un ingreso no constitutivo de renta ni ganancia ocasional determinados de conformidad con el inciso 1 del Artículo 245 del ET, la tarifa es del 7,5\% es decir que podría resultar más favorable para el inversionista si se tiene en cuenta que se establece un tope del $15 \%$ para los casos en que el beneficiario efectivo es una sociedad que no posee directamente al menos el $25 \%$ del capital de la sociedad que paga los dividendos.

Sin embargo, los CDI pueden manejar unos topes o porcentajes inferiores; tal es el caso de los convenios suscritos por Colombia, los cuales manejan diferentes tarifas, y como regla general los dividendos son exentos o presentan tarifa cero cuando el beneficiario efectivo es una sociedad que posea directa o indirectamente al menos un porcentaje que oscila entre el $20 \%$ o el $25 \%$ del capital de la sociedad que paga los dividendos.

Conviene precisar que, para efectos de la aplicación de este artículo, no se tiene en cuenta ninguna diferencia respecto a las clases de acciones del que proviene el dividendo, es decir, los topes establecidos en cada convenio se deben cumplir sin importar si se trata de acciones de sociedad anónimas (que para este trabajo son las que interesan) ordinarias, con voto preferente, etc.

\section{- Artículo 11 de los CDI. Intereses}

Se entiende por interés el retorno de deuda, la cual por lo general se consigue a través de instrumentos crediticios que implica el pago de intereses fijos o variables, así mismo se incluyen instrumentos de deuda conocidos como híbridos, entre los cuales se encuentran valores como los bonos convertibles en acciones, bonos participativos, etc.

Según Idrovo citado por (Rohatgi, 2008), la diferencia entre capital y deuda puede considerarse que radica en que el capital soporta los riesgos empresariales en tanto la deuda no los comparte y los derechos de los deudores prevalecen sobre los de los accionistas. Sin embargo, en algunas oportunidades la deuda y el capital pueden confundirse y este es el caso de los bonos convertibles en acciones, los cuales serán tratados como deuda hasta tanto no suceda su conversión. 
Tabla 3.

Tarifas gravamen a los Dividendos CDI suscritos por Colombia.

\begin{tabular}{|c|c|}
\hline CDI & Tarifa aplicable \\
\hline $\begin{array}{l}\text { España. Ley } \\
1082 \text { de } 2006\end{array}$ & $\begin{array}{l}\text { Regla General es del } 5 \% \text { del importe bruto de los dividendos. } \\
\text { Excepción. Es el } 0 \% \text { del importe bruto de los dividendos si el beneficiario efectivo es una socie- } \\
\text { dad que posea directa o indirectamente al menos el } 20 \% \text { del capital de la sociedad que paga los } \\
\text { dividendos. }\end{array}$ \\
\hline $\begin{array}{l}\text { Chile. Ley } 1261 \\
\text { de } 2008\end{array}$ & $\begin{array}{l}\text { Regla General. } 7 \% \text { del importe bruto de los dividendos en todos los demás casos. } \\
\text { Excepción. } 0 \% \text { del importe bruto de los dividendos si el beneficiario efectivo es una sociedad que } \\
\text { posea directamente al menos el } 25 \% \text { del capital de la sociedad que paga los dividendos. }\end{array}$ \\
\hline Ley 1344 & $\begin{array}{l}\text { Regla General. Es del } 15 \% \text { del importe bruto de los dividendos en los demás casos. } \\
\text { Excepción: } 0 \% \text { del importe bruto de los dividendos si el beneficiario efectivo es una sociedad que } \\
\text { posea directa al menos el } 20 \% \text { del capital de la sociedad que paga los dividendos. }\end{array}$ \\
\hline $\begin{array}{l}\text { Ley } \\
011\end{array}$ & $\begin{array}{l}\text { Regla General. } 15 \% \text { del importe bruto de los dividendos en todos los demás casos. } \\
\text { Excepción. } 5 \% \text { del importe bruto de los dividendos si el beneficiario efectivo es una sociedad } \\
\text { que controla directa o indirectamente al menos el } 10 \% \text { de las acciones con derecho a voto de la } \\
\text { sociedad que paga los dividendos. }\end{array}$ \\
\hline & $\begin{array}{l}\text { No presenta tarifas. } \\
\text { Se establece exclusividad en la imposición en el país de la residencia. Los dividendos pagados por } \\
\text { una sociedad residente de un Estado Contratante a un residente del otro Estado Contratante solo } \\
\text { pueden someterse a imposición en este otro Estado. }\end{array}$ \\
\hline $\begin{array}{l}\text { lel Sur. } \\
67 \text { de } 2013\end{array}$ & $\begin{array}{l}\text { Excepción. } 5 \% \text { del importe bruto de los dividendos si el beneficiario efectivo es una sociedad } \\
\text { (excluidas las sociedades de personas - partnerships-) que posea directamente al menos el } 20 \% \\
\text { al de la sociedad que paga los dividendos, } \\
\text { Regla General. } 10 \% \text { del importe bruto de los dividendos en todos los demás casos. }\end{array}$ \\
\hline $\begin{array}{l}\text { Portugal. Ley } \\
1692 \text { de } 2013\end{array}$ & $\begin{array}{l}\text { Tarifa Única. Si el beneficiario efectivo de los dividendos es un residente del otro Estado Contra- } \\
\text { tante, el impuesto exigido no podrá exceder del } 10 \% \text { del importe bruto de los dividendos. }\end{array}$ \\
\hline $\begin{array}{l}\text { India. Ley } 1668 \\
\text { de } 2013\end{array}$ & $\begin{array}{l}\text { Tarifa Única. Si el beneficiario efectivo de los dividendos es un residente del otro Estado Con- } \\
\text { tratante, el impuesto así exigido no podrá exceder del } 5 \% \text { del importe bruto de los dividendos. }\end{array}$ \\
\hline $\begin{array}{l}\text { Republica } \\
\text { Checa. Ley } 1690 \\
\text { de } 2013\end{array}$ & $\begin{array}{l}\text { Excepción. } 5 \% \text { del importe bruto de los dividendos si el beneficiario efectivo es una sociedad } \\
\text { (excluidas las sociedades de personas - partnerships-) que posea directamente al menos el } 25 \% \\
\text { del capital de la sociedad que paga los dividendos. } \\
\text { Regla General. Es del } 15 \% \text { del importe bruto de los dividendos en los demás casos. } \\
\text { En el caso de los dividendos pagados por una sociedad residente en Colombia procedentes de } \\
\text { utilidades no gravadas en Colombia de acuerdo con su legislación doméstica, dichos dividendos } \\
\text { también podrán ser sometidos a imposición en Colombia según la legislación de Colombia, pero } \\
\text { si el beneficiario efectivo de dichos dividendos es un residente en la República Checa el impuesto } \\
\text { exigido en Colombia no podrá exceder del } 25 \% \text { del importe bruto de los dividendos. }\end{array}$ \\
\hline
\end{tabular}

Fuente: Ministerio de Hacienda (2019).

El Artículo 11 de los CDI del modelo OCDE define este tipo de ingreso como "las rentas de créditos de cualquier naturaleza, con o sin garantía hipotecaria o cláusula de participación en los beneficios del deudor, y en particular las rentas de valores públicos y las rentas de bonos y obligaciones, incluidas las primas y premios unidos a esos títulos".
En el ordenamiento andino, el Artículo 2 de la Decisión 578 de 2004 define como interés los rendimientos de cualquier naturaleza, incluidos los rendimientos financieros de créditos, depósitos y captaciones realizados por entidades financieras privadas, con o sin garantía hipotecaria, o cláusula de participación en los beneficios del deudor, 
y especialmente, las rentas provenientes de fondos públicos (títulos emitidos por entidades del Estado) y bonos u obligaciones, incluidas las primas y premios relacionados con esos títulos, excluyéndose de este los intereses por concepto de mora.

De las definiciones anteriores, tal como lo expone Ruth Yamile Younes (2010), se puede concluir que lo dispuesto en el Artículo 11 de modelo de la OCDE, no aplica a los derivados financieros, en razón a que en este tipo de operación no se realiza la transferencia de capital.

Dentro de las operaciones que puede realizarse en el mercado público de valores, se encuentra la compra y venta de todo derecho de naturaleza negociable que haga parte de una emisión, cuando tenga por objeto o efecto la captación de recursos del público.

Entre los valores que encontramos cuyo ingreso puede cualificarse como interés se encuentran los títulos de renta fija, como los bonos (ordinarios, multilaterales), los bonos convertibles en acciones hasta tanto no se redimen, los bonos hipotecarios, los TES (Títulos de deuda pública), las aceptaciones bancarias, los papeles comerciales, los CDT, así como los valores en proceso de titularización, entre otros.

La tributación internacional de este tipo de ingreso puede implicar una doble imposición, si se tiene en cuenta que en algunos Estados se grava a través de la retención en la fuente sobre los intereses cuando el deudor los paga y, posteriormente, en el país de residencia se considera como un ingreso para su acreedor, efecto que puede neutralizarse si los Estados -tanto el de residencia como el de la fuente-tienen suscrito un CDI bajo el amparo del referido Artículo 11.

Respecto a este tipo de renta, también se debe tener presente la cualificación del sujeto pasivo a quien se le debe practicar la retención en lo relativo al beneficiario efectivo, pues en el evento de que el inversionista actúe a través de un tercero a quien se le paga el interés pero que en realidad no tiene la facultad de disponer sobre ese pago, no será posible aplicar el convenio.

Sin embargo, en la práctica para los Estados resulta una tarea compleja determinar quién ostenta la calidad de destinatario efectivo y más en una operación de portafolio; al respecto, la DIAN ha indicado que la Administración Tributaria "no puede de manera general determinar si quien percibe el ingreso puede tener la consideración de beneficiario efectivo, y en consecuencia, aplicar la limitante a la potestad tributaria nacional respecto de estos pagos", ya que "para ello se requerirá que el pagador de los rendimientos del Estado fuente pueda conocer determinados aspectos acerca de quien recibe dichos pagos de los mismos, de tal suerte que delimite su responsabilidad" (Concepto $\left.{ }^{\circ} .1147,2016\right)$, lo que significa que la administradora local deberá conocer a su cliente extranjero para determinar si debe o no aplicar la limitante del convenio.

De acuerdo con este artículo, los ingresos provenientes de pago de intereses por regla general soportan un gravamen en el Estado de la fuente con unos límites respecto a la tarifa; sin embargo, al igual que con los dividendos, se le reconoce la facultad al Estado de la residencia para gravar los ingresos provenientes del pago de intereses. 
De esta manera, el país de la fuente -Colombia-, solo podría gravar dicho pago con una tarifa reducida que no puede exceder del $10 \%$, la cual resulta más favorable si se tiene en cuenta que la tarifa general que establece el literal e) del Artículo 18-1 del ET, es del 14\% si el inversionista no se encuentra domiciliado en una jurisdicción de baja imposición.

El límite en la tarifa de retención en la fuente que consagra el Artículo 11 deja en desventaja al inversionista local respecto del extranjero cuyo Estado de residencia tiene suscrito el CDI, puesto que una persona jurídica residente fiscal en Colombia deberá tributar por dicho ingreso a la tarifa del $25 \%$ para las rentas obtenidas antes del primero de enero de 2017 pues con la Ley 1819 de 2016 se establece en el 33\%.

Sin embargo, el techo o límite que presenta el Artículo 11 del modelo OCDE en algunos casos no se aplica por los Estados. Claro ejemplo de ello se encuentra en la tarifa que se estableció en el CDI suscrito entre Colombia y Chile, en el cual se determinó una tarifa del 5\% del importe bruto de los intereses si el beneficiario efectivo de estos es un banco o una compañía de seguro y del $15 \%$ en los demás casos, siendo esta última un punto más alto que la establecida en el ordenamiento colombiano.

Respecto al deudor, el Artículo 24 del CDI establece que el país de residencia de este deberá tener la oportunidad de deducir en el impuesto sobre las rentas de un valor igual al impuesto pagado en ese otro Estado; sin embargo, dicha deducción no podrá exceder de la parte del impuesto, calculado antes de la deducción, correspondiente a las rentas obtenidas en ese otro Estado.

\section{- Artículo 13. Ganancias de capital}

Como regla general, este artículo establece que el Estado que puede gravar este tipo de renta es el de residencia; sin embargo, ello no es óbice para que el país de la fuente también grave este tipo de ingresos. En el ordenamiento andino, la Decisión 578 de 2004 determina que se debe gravar la renta en el Estado de la fuente, es decir donde se encuentren los bienes y en la enajenación de títulos, acciones u otro tipo de valores, se grava en el país en donde se emiten.

Entre aquellas rentas que se regularían por este artículo y que interesan a este trabajo se encuentran aquellas realizadas a largo plazo o las de corto plazo, así como las conocidas como ganancias especulativas (enajenación de acciones).

El Artículo 13 de los CDI no define expresamente qué se entiende por ganancia de capital; sin embargo, de la lectura integral del artículo se puede deducir que se refiere a aquellas rentas que se obtienen al enajenar bienes. En el ámbito de la Decisión 578 de 2004, el literal j) del Artículo 2 establece como ganancia de capital el beneficio obtenido por una persona en la enajenación de bienes que no adquiere, produce o enajena habitualmente dentro del giro ordinario de sus actividades.

El apartado quinto del referido Artículo 13 del modelo de la OCDE incluye toda la enajenación de bienes que no fueron tratados de manera expresa en los apartados 1,2,3 y 4, es decir, las que no tengan que ver con enaje- 
nación de propiedad inmobiliaria, propiedad mobiliaria que forme parte de un activo de un establecimiento permanente, naves, aeronaves, buques, etc., dentro de los cuales clasificarían las acciones de sociedades que no estén incluidas en los numerales anteriores y que, para este trabajo, se negocian en el mercado público de valores.

Es necesario resaltar que de acuerdo con los Comentarios presentados al Modelo de Convenio Tributario sobre la Renta y sobre el Patrimonio del 22 de julio de 2010, respecto con la enajenación de acciones en el mercado público de valores de uno de los Estado contratantes se indicó en el apartado 4 del Artículo 13 que las ganancias obtenidas por un residente de un Estado contratante en la enajenación de acciones, en las que más del $50 \%$ de su valor procede, de forma directa o indirecta, de propiedad inmobiliaria situada en el otro Estado contratante, pueden gravarse en este último. Sobre el particular se indicó:

(...) no debe aplicarse a las ganancias derivadas de la enajenación de acciones de sociedades que cotizan en un mercado de valores reconocido de uno de los Estados, ni tampoco a las ganancias obtenidas en la enajenación de acciones habidas en una reorganización de sociedades o cuando la propiedad inmobiliaria de donde procede el valor de las acciones sea aquella (por ejemplo, una mina o un hotel) donde se realiza la actividad mercantil. Los Estados que deseen incluir una o más de estas excepciones son libres de hacerlo.

De otra parte, se destaca que este artículo limita el poder impositivo del Estado de la fuente, pues establece que " 5 . Las ganancias derivadas de la enajenación de cualquier otro bien distinto de los mencionados en los apartados 1,2,3 y 4 pueden someterse a imposición sólo en el Estado contratante en que resida quien enajena".

Sin embargo, esta regla no es absoluta, pues existen algunos CDI suscritos por Colombia en los cuales se le permite al Estado donde se encuentra ubicada la sociedad gravar dicho ingreso; tal es el caso del CDI suscrito con Chile, en el cual se establece en el apartado 4 la posibilidad de que el Estado donde se encuentre la sociedad grave las ganancias de capital, siempre y cuando provengan de la enajenación de acciones cuyo valor se derive directa o indirectamente en más de un $50 \%$ de bienes inmuebles situados en el otro Estado Contratante (esta regla también se aplica en el CDI suscrito con India), $o$ cuando el perceptor de la ganancia haya poseído, en cualquier momento dentro del período de doce meses precedentes a la enajenación, directa o indirectamente, acciones u otros derechos consistentes en un $20 \%$ o más del capital de esa sociedad.

Sin embargo, la regla anterior no aplica cuando se trata de un fondo de pensiones que reside en un Estado contratante, ya que en el evento que este perciba ingresos por enajenación de acciones de una sociedad que reside en el otro Estado Contratante, solo podrá gravarse el ingreso en el Estado donde resida el fondo de pensión, regla igualmente aplicable para el CDI suscrito con Corea del Sur.

De otra parte, en el CDI entre Colombia y México se advierte que se establece la posibilidad de que el Estado contratante de la fuente, es decir Colombia, si: a) provienen 
de la enajenación de acciones cuyo valor se derive directa o indirectamente en más de un $50 \%$ de bienes inmuebles situados en el otro Estado Contratante, o b) el perceptor de la ganancia ha poseído, en cualquier momento dentro del periodo de doce meses precedentes a la enajenación, directa o indirectamente, acciones u otros derechos consistentes en un $20 \%$ o más del capital de esa sociedad. Las anteriores reglas son similares a las aplicables en el CDI con Corea del Sur.

En algunos CDI se presenta una disposición residual, en virtud de la cual se permite al Estado de la fuente o en el que residen las sociedades cuyas acciones se enajenan someterse a imposición en ese Estado, como lo dispone el apartado 5 del CDI suscrito con India.

Este artículo no indica una fórmula para determinar la base gravable del tributo ni establece un límite o techo en la tarifa, lo que significa que ello quedará al arbitrio del Estado de residencia del enajenante. Sin embargo, analizando el Artículo 13 de los CDI suscritos por Colombia, se observa que algunos de ellos sí establecen una tarifa o techo para gravar estas rentas respecto al Estado de la fuente.

Un ejemplo claro de lo anterior se encuentra en el CDI suscrito con Chile, en el cual se preceptúa un límite en la tarifa del $17 \%$, respecto de la "ganancia obtenida por un residente de un Estado Contratante por la enajenación de acciones u otros derechos representativos del capital de una sociedad residente en el otro Estado Contratante". Esta tarifa resulta ser más gravosa si se tiene en cuenta que de acuerdo con el Artículo 18-1 del ET, la enajenación se encuentra gravada en un $14 \%$ siempre que no se encuentre do- miciliado el inversionista en una jurisdicción considerada como paraíso fiscal.

Respecto al CDI suscrito con México y Portugal, también se presenta un techo en la tarifa a aplicar en el gravamen por la enajenación de acciones u otros derechos representativos para el Estado de la fuente, la cual no podrá exceder el $20 \%$ del monto de la ganancia, siendo en este caso, menos gravosa la tarifa establecida por el referido Artículo 18-1 de ET. Conviene destacar que este techo aplicable a la tarifa en el CDI con Portugal aplica en la enajenación de acciones u otro derecho de representación cuando el residente del primer Estado de la residencia de la sociedad posea, en cualquier momento dentro de un periodo de doce meses anteriores a la enajenación, el 25\% o más del capital de dicha sociedad.

Por último, frente a los instrumentos de derivados financieros con entrega, algunos tratadistas consideran que es posible que las rentas obtenidas en este tipo de operación puedan regularse como ganancias de capital.

\section{- Artículo 21. Otras rentas}

El Artículo 21 de los CDI es residual, lo que implica que aquellas rentas respecto de las cuales no se haya establecido una regulación especial en los artículos precedentes deben regirse por lo que disponga este artículo. Al efecto, para este estudio interesa este artículo en aquellas rentas provenientes de las operaciones de derivados financieros, en las cuales su renta será tratada de acuerdo con la naturaleza del subyacente, pues de acuerdo con este podría calificarse la renta como un interés, una ganancia de capital o simplemente no atender a ninguna de las rentas reguladas en los artículos 10,11 o 13 . 
Esto implica que dicha renta se deba regular bajo lo dispuesto por el Artículo 21 del CDI, en virtud de cual se establece en su apartado primero que "las rentas de un residente de un Estado contratante, cualquiera que fuese su procedencia, no mencionadas en los anteriores artículos del presente Convenio sólo pueden someterse a imposición en ese Estado".

De acuerdo con lo anterior, se establece que en el evento que un instrumento financiero como por ejemplo un derivado y su renta se regule por este artículo, Colombia no podría entrar a gravar por este ingreso al inversionista extranjero, pues se determina de manera expresa que corresponderá es al país de la residencia del inversionista la potestad de gravarlo.

Lo anterior no es óbice para que los Estados puedan hacer reservas de este precepto y mantener la potestad de gravar las rentas que se produzcan en su jurisdicción, tal como sucede con los países de Canadá, Chile, México y Portugal, los cuales determinan:

(...) las rentas de un residente de un Estado Contratante no mencionadas en los artículos anteriores del presente Convenio y que provengan del otro Estado Contratante pueden someterse a imposición en ese otro Estado.

En el caso del CDI suscrito con Canadá, además de reservarse la facultad de que se pueda gravar el ingreso en el Estado de la fuente, se preceptúa que cuando dichas rentas sean rentas de un fideicomiso distinto a un fideicomiso en el que los aportes hayan sido deducibles, el impuesto así exigido no excederá del $15 \%$ del monto bruto de las rentas, siempre que el beneficiario efectivo resida en Colombia y las rentas estén sometidas a imposición en Colombia.

\section{G. Las pérdidas acumuladas pueden ser amortizadas sin lapso determinado y las retenciones practicadas en exceso en un periodo de 12 meses - transición de la norma}

El numeral 7 del Artículo 18-1 del ET establece dos reglas de gran importancia para el inversionista extranjero de portafolio, las cuales permiten dentro de un marco de equidad equipararlo al residente fiscal.

Al efecto, a partir del $1^{\circ}$ de enero de 2013, se le permite al inversionista extranjero que las pérdidas sufridas en un mes y cuya deducibilidad no se encuentre limitada para los residentes, puedan ser amortizadas con las utilidades que este obtenga en los meses subsiguientes. Así mismo, se le permite descontar las retenciones en exceso dentro de un lapso de 12 meses siguientes.

Lo anterior alivia los problemas que se presentaban con las sumas de retenciones en la fuente practicadas en exceso que se arrastraban periodo tras periodo y que se constituía en un saldo a favor que en muchos casos no era posible recuperar. También, es necesario resaltar que en la actualidad no se presentarán las retenciones en exceso, pues con el sistema adoptado por la Ley 1607 de 2012, ya no se generarán las cadenas de retenciones en la fuente que se practicaban con cada pago o abono en cuenta, pues ahora solamente el administrador es el que realiza dicha retención por una sola vez al finalizar la operación mensualmente, circunstancia que quedó nuevamente ratificada con la Ley 1943 de 2018. 
Frente a las pérdidas obtenidas en las operaciones de portafolio, la norma es muy benévola en el sentido de permitir sin límite de tiempo deducirlas con la utilidades posteriores; sin embargo, esta norma trajo una norma de transitoriedad que estableció un límite en el tiempo para las pérdidas obtenidas con anterioridad a su entrada en vigencia, es decir, aquellas sufridas antes del $1^{\circ}$ de enero de 2013, dando un periodo de transición de doce meses que en algunos casos no fue el suficiente para que el inversionista pudiera recuperarlas.

Debido a la normativa que regía antes del $1^{\circ}$ de enero de 2013, y en vista de que no existía una normativa clara para la depuración del impuesto en las operaciones de portafolio, una vez restados los efectos de la devaluación del peso con relación a la moneda del dólar y aplicados los gastos de administración, se presentaron grandes pérdidas para el inversionista $y$, con ello, las retenciones practicadas en exceso durante el año 2012 no se pudieron descontar en su totalidad durante los siguientes 12 meses.

De esta manera, el periodo de transición que consagró la norma resultó muy corto para la amortización de las pérdidas acumuladas que venía presentando el inversionista extranjero, quien no tuvo más opción que recurrir directamente ante la Administración Tributaria para solicitar las sumas retenidas en exceso por concepto de rendimientos financieros, las cuales constituyen un pago de lo no debido y/o pago en exceso, si se tiene en cuenta que antes de la reforma del año 2012, el inversionista extranjero no se consideraba contribuyente del impuesto sobre la renta y, por ende, la retención practicada no podía ser considerada como impuesto definitivo.
Frente a lo anterior, la respuesta de la DIAN contenida en el Concepto $n^{\circ} .0381121$ de 25 de junio de 2014 no dio una solución al inversionista, ya que determinó que al no ser reguladas por la Ley 1607 de 2012, las devoluciones de las sumas retenidas en exceso por concepto de impuesto sobre la renta de los rendimientos financieros obtenidos en las inversiones de portafolio antes del $1^{\circ}$ de enero de 2013 , no es posible acceder a la devolución. Además, puntualizó que la referida reforma del año 2012 no "prevé un mecanismo diferente al del descuento para obtener el reconocimiento de retenciones que resulten en exceso".

Con esta conclusión se estaría usurpando la función del legislativo, al crear una nueva causal de rechazo de las devoluciones, las cuales se encuentran establecidas de forma taxativa en el Artículo 857 del ET, como lo son: i) cuando se presenta extemporáneamente; ii) el saldo materia de la solicitud ya ha sido objeto de devolución, compensación o imputación anterior, y iii) cuando dentro del término de la investigación previa de la solicitud de devolución o compensación, como resultado de la corrección de la declaración efectuada por el contribuyente o responsable, se genera un saldo a pagar.

La última palabra respecto a si la Administración debe devolver las sumas retenidas en exceso la tiene la jurisdicción Contenciosa Administrativa, concretamente la Sección Cuarta del Consejo de Estado, que deberá definir si procede o no la devolución del pago en exceso realizado por el inversionista extranjero.

En primera instancia, la Subsección B de la Sección Cuarta del Tribunal Administrativo de Cundinamarca dispuso decretar la 
nulidad del acto que negó la devolución bajo el argumento de que existe un trámite general de las devoluciones y/o compensaciones establecido en el Artículo 850 y siguientes del Estatuto Tributario, el cual debió aplicar la Administración en este caso y en su momento valorar si existe el pago en exceso aludido por el contribuyente. Y, por último, ordenó a la DIAN devolver las sumas pagadas al determinar que al quedar un exceso en las retenciones practicadas no puede considerarse este como el impuesto definitivo por no poderse compensar, pues "ello implicaría subordinar el impuesto realmente a cargo, al resultado de un impuesto o instrumento o medio de recaudo del mismo (Sentencia Exp. 2015-0026, 2016)".

\section{H. Traslado de cuentas del mismo titular en el mismo establecimiento, se encuentran exentas de GMF de acuerdo con el numeral 14 del Artículo 879 del Estatuto Tributario}

La Ley 1607 de 2012 consagró un gran beneficio a los inversionistas de portafolio del exterior, al establecer exento el gravamen sobre los movimientos financieros el traslado entre inversiones siempre que estos pertenezcan a un mismo y único titular y estén abiertos en la misma entidad vigilada por la Superintendencia Financiera. Sin embargo, debe precisarse que los traslados que son exentos del GMF a la luz del numeral 14 del Artículo 879 del ET, son únicamente aquellos efectuados por una sociedad comisionista de Bolsa, una sociedad fiduciaria o una sociedad administradora de inversión, vigilada por la Superintendencia Financiera.

De acuerdo con el Artículo 1.4.2.2.16 del Decreto Único Tributario, el cual recopila lo dispuesto en el Artículo 8, Decreto 660 de 2011, modificado por el Artículo 4 del Decreto 1744 de 2013 y los numerales 7, 8 y 9 y el parágrafo 2 adicionados por el Artículo 2 del Decreto 1489 de 2015, se expone que para aplicar la referida exención se entiende por inversiones todos aquellos valores que se encuentran inscritos en el Registro Nacional de Valores, los valores listados en sistemas de cotización de valores del extranjero, participaciones en fondos de inversión colectiva, divisas, e instrumentos transados en las Bolsas de productos agropecuarios y otros commodities.

\section{Reforma Tributaria contenida en la Ley 1739 de 2014. Excluye del impuesto a la riqueza a los inversionistas de portafolio del exterior}

En el año 2014 y ante la urgencia de conseguir recursos suficientes para cumplir con el alto gasto social del Gobierno Central que ese año había ascendido a 9,6 como porcentaje del PIB y para el año 2015, sería del 9,4 del PIB (CEPAL -Naciones Unidas, 2016), se realizó una nueva reforma al ordenamiento tributario que sin bien no fue estructural como en su momento fue solicitado por los diferentes sectores de la economía, sí presentó algunos efectos nocivos a nivel de la inversión extranjera directa en Colombia, al crear un nuevo impuesto a la riqueza.

$\mathrm{Al}$ estudiar el impuesto a la riqueza establecido en el Artículo primero de la Ley 1739 de 2014, que adicionó el Artículo 292-2 al ET, se puede inferir que si bien, de la forma de depurar la base gravable de este tributo se permite detraer conceptos como las acciones y las cuotas o partes de interés en sociedades nacionales poseídas directamente o a través 
de fiducias mercantiles o fondos de inversión colectiva, o el valor de las operaciones activas de crédito realizadas con residentes fiscales colombianos o sociedades nacionales, sí le impuso al inversionista extranjero directo la obligación formal de declarar.

Frente al inversionista de portafolio del exterior, el Artículo 2 de la Ley 1739 de 2014, que adicionó el Artículo 193-2, estableció que "no son contribuyentes del impuesto a la riqueza" las personas naturales, entidades o sociedades de los que trata el Artículo 18-1 del ET, lo que significa que no se predica la subjetivad pasiva de este tributo.

Sobre la justificación a esta exclusión del impuesto se argumentó en la exposición de motivos de la Ley 1739 que "solo en algunos casos se excluye de la aplicación del Impuesto a la Riqueza a personas que son contribuyentes del Impuesto sobre la Renta", tal como sucedió con los inversionistas de capital del exterior de portafolio, a quienes, a pesar de haber sido calificados como contribuyentes del impuesto sobre la renta en la Ley 1607 de 2012, por la naturaleza de los activos que poseen y, "en aras de no afectar gravemente el desarrollo del mercado de capitales, el cual es altamente sensible a la imposición de nuevos gravámenes, así como de ciertos deberes formales, tales como la presentación de declaraciones de impuestos" (Gaceta no. 575, 2014).

\section{Reforma estructural al sistema tributario colombiano. Ley 1819 de 2016}

Nuevamente en el año 2016 se efectuó una reforma tributaria, que resultó un poco compleja y demasiado extensa que la presentada en el año 2014. Esta reforma tenía un escena- rio especial, no fue ideada y elaborada únicamente por el Ejecutivo, pues de acuerdo con lo ordenado en la Ley 1739 de 2014, se contó con la ayuda de un Comité de Expertos, los cuales elaboraron un informe que permitió identificar los problemas y complejidades del sistema tributario, así como convertirse en el punto de partida para la elaboración de esta reforma.

Frente a la inversión de portafolio del exterior, se puede decir que la reforma presentada en el año 2012 ha sido tan efectiva en la regulación tributaria respecto de las operaciones del mercado de valores, que el Artículo 18-1 del ET no sufrió ninguna modificación. Sin embargo, la Ley 1819 de 2016 trajo algunas modificaciones sobre los dividendos, los cuales han afectado colateralmente al inversionista de portafolio no residente en el país, así como la incorporación de un beneficio para los fondos de pensiones y cesantías que son administradas por sociedades extranjeras y que son supervisadas por entidades extranjeras que han suscrito convenios de intercambio de información con la entidad de vigilancia y control colombiana.

\section{A. Modificación en materia de dividendos}

El Artículo 7 de la Ley 1819 de 2016 modificó el Artículo 245 del ET, que regula la tarifa especial para dividendos y participaciones recibidos por sociedades y personas naturales no residentes y que establece que el impuesto sobre la renta correspondiente a dividendos y participaciones que no son residentes en Colombia es de una tarifa del 5\%. Este precepto también establece que en el evento que los dividendos o participaciones de una sociedad nacional hubieren estado gravadas de acuerdo con lo establecido en 
los artículos 48 y 49 del ET, debe aplicárseles una tarifa del $35 \%$ sobre lo pagado o lo abonado en cuenta, lo que significa que para aplicar la tarifa del $5 \%$ se debe realizar una vez disminuido dicho impuesto.

Al efecto, antes del 4 de septiembre del 2018 se tenía la incertidumbre respecto al alcance del aludido precepto en relación con la inversión de portafolio extranjera, en razón a que este tipo de inversión tiene su régimen especial que regula una tarifa del $25 \%$ para aquellos dividendos gravados con ocasión de las operaciones de portafolio de inversión.

La Administración Tributaria emitió el Concepto $\mathrm{n}^{\circ} .024422$ de 4 de septiembre de 2018, en el cual manifestó que, pese a que la inversión de portafolio tiene su propio ordenamiento jurídico tributario respecto al impuesto sobre los dividendos, de acuerdo con la lectura del Artículo 245 del ET, se establece que la tarifa del $5 \%$ especial es para todos los contribuyentes que sean personas naturales o jurídicas no residentes en el país.

Lo anterior lleva a colegir que los dividendos obtenidos por un inversionista extranjero de portafolio, quedaran gravados de la siguiente forma:

a) La tarifa especial aplicable sobre los dividendos gravados en cabeza del accionista que corresponde a utilidades no gravadas en cabeza de la sociedad, es la contenida en el Artículo 18-1 del ET, esto es, $25 \%$ y sobre el remanente a distribuir, a su turno se aplicará el 5\%. Esto resulta en una tarifa efectiva de $28,75 \%$.

b) En caso de dividendos gravados en cabeza de la sociedad y por ende, no ser gravados en cabeza del accionista, la tarifa aplicable será del $5 \%$ al momento del pago.

Sin embargo, debe dejarse claro que el anterior impuesto especial a los dividendos se deberá practicar únicamente a aquellas utilidades que se presenten con posterioridad al primero de enero de 2017 para que, de esta manera, los dividendos que se repartan con cargo a utilidades anteriores a la entrada en vigencia de la Ley 1819 de 2016 y que fueren decretados y exigibles posteriormente (no interesa si a la fecha no han sido decretados, puesto que con anterioridad al $1^{\circ}$ de enero de 2017 no existía el impuesto a la dividendos), no se encuentran gravados, en desarrollo con el régimen de transición establecido en el Artículo 246-1 del ET, lo que fue confirmado por la DIAN mediante los conceptos 0042 de 2 de febrero de 2019 y 00612 de 13 de marzo de 2019.

La retención en la fuente a título del impuesto sobre la renta que debe practicarse al inversionista extranjero de portafolio se deberá realizar en los términos del Artículo 2 del Decreto 640 de 2018, que adicionó el Artículo 1.2.4.7.4, del Decreto Único Tributario y en el cual se determina que como primera medida la sociedad administradora deberá informar a la sociedad pagadora del dividendo la calidad del inversionista, es decir, si es persona natural o jurídica y si es o no residente fiscal para que esta practique la respectiva tarifa de retención que en este caso es el impuesto definitivo.

Pese a todo lo anterior, en este reforma se introdujo una exención del gravamen a los movimientos financieros - GMF, que ayudó de manera considerable al inversionista 
extranjero, pues de acuerdo con el Artículo 217 de la Ley 1819 de 2016, se consideran exentos de este gravamen la compra de divisas que tengan como único propósito la repatriación de recursos para las inversiones de portafolio, creándose por parte del Banco de la República un nuevo numeral cambiario que permite hacer efectiva dicha exención.

\section{B. Beneficio regulado en el Artículo 23-2 del ET}

La Ley 1819 de 2016 introdujo un beneficio para la inversión extranjera de portafolio que consiste en no practicar retención en la fuente ni obligar a declarar a aquellos fondos de pensiones y cesantías que se encuentren administrados por sociedades extranjeras sometidas a la supervisión de autoridades con las cuales el ente de supervisión colombiano, es decir, la Superintendencia Financiera haya suscrito acuerdos o convenios de intercambio de información (parágrafo del Artículo 23-2 ET). Con este beneficio tributario, Colombia busca fortalecer el mercado de valores colombiano, integrándolo con aquellos vehículos de inversión extranjera, haciéndolo llamativo al no encontrarse gravados en el país y retirándole la obligación formal de declarar.

En este punto conviene resaltar que los acuerdos de información a que hace referencia este beneficio no son los acuerdos de información tributaria que ha suscrito Colombia con otras jurisdicciones como FATCA o CRS (Common Reporting Standard), puesto que los convenios de que trata el parágrafo del Artículo 23 -2 del ET son aquellos en los cuales se obtiene todo tipo de información sobre estos fondos, desde las personas que las dirigen, como gerentes, administradores, las operaciones que son supervisadas hasta información financiera o contable, apartándose la información tributaria.

La DIAN, en el año 2018, señaló los tres países con los cuales se tienen suscritos estos convenios de información o protocolos de supervisión, entre los que se encuentran: Perú (Superintendencia de Banca, seguros y administradoras privadas de fondos de pensiones), Canadá (Office the Superintendent oh financial institutions) y México (Comisión Nacional del Sistema de Ahorro para el retiro de los Estados Unidos Mexicanos) y precisó que con aquellos países con los cuales se tenga suscrito un memorando de entendimiento no procede el referido beneficio, toda vez que la norma expresamente indica que se trata de convenios de información o protocolos de supervisión (Oficio 012100, 2018).

La anterior posición de la entidad fiscal se considera una interpretación eminentemente literal de la norma que no logra cumplir con los objetivos de la misma, puesto que Colombia ha suscrito con diferentes países como Brasil, Chile, Costa Rica, Ecuador, España, Islas Caimán, entre otros, memorandos de entendimiento para efectos de intercambio de información y cooperación para la supervisión transfronteriza, los cuales, al realizarse su lectura, cumplen con el mismo objeto de los convenios de información y/o protocolos de supervisión.

Existen algunas jurisdicciones o autoridades provinciales de Canadá con las cuales tienen suscrito convenios de información o protocolos de supervisión (Oficio $\mathrm{n}^{\circ}$. 2018120946-003, 2018): 
Tabla 4.

Convenios de información o protocolos de supervisión suscritos por Colombia

\begin{tabular}{l|l}
\hline PROVINCIA & Autoridad de supervisión \\
\hline ALBERTA & Alberta Treasury Board and Finance \\
\hline BRITISH COLUMBIA & Financial Institutions Commission \\
\hline MANITOBA & Office of the Superintendent - Pension Commission \\
\hline NOVA SCOTIA & Finance and Treasury Board - Pension Regulation Division \\
\hline NEW BRUNSWICK & Financial and Consumer Services Commission \\
\hline NEWFOUNDLAND AND LABRADOR & Government of Newfoundland and Labrador - Pension Benefit Standards Division \\
\hline ONTARIO & Financial Services Commission of Ontario \\
\hline QUÉBEC & Retraite Québec \\
\hline SASKATCHEWAN & Financial and Consumer Affairs Authority of Saskatchewan \\
\hline
\end{tabular}

Fuente: Superintendencia Financiera (2019).

\section{C.Leyde Financiamiento-Ley 1943 de 2018}

El año pasado en Colombia se tramitó la conocida Ley de Financiamiento, con la cual (Congreso de la República, Gaceta n ${ }^{\circ} .933$, 2018) se busca cumplir cinco objetivos: i) balancear el Presupuesto General de la Nación para la vigencia 2019, ii) aumentar el crecimiento económico: iii) avanzar en la progresividad tributaria, iv) simplificar el sistema tributario y v) garantizar la sostenibilidad fiscal del país.

La ley 1943 de 2018 trajo algunas modificaciones para el sector financiero, entre las cuales se pueden destacar: i) creó unos puntos adicionales a la tarifa del impuesto sobre la renta de las entidades financieras; ii) se actualizó el impuesto de timbre, respecto de los cheques, bonos nominativos y al portador, así como las garantías otorgadas por los establecimientos de crédito; iii) se presentan nuevas reglas de subcapitalización, como por ejemplo se aclara que estas solo se aplican a aquellos intereses de créditos que se toman con vinculados económicos nacionales o extranjeros, y iv) se derogan las normas que establecían que el componente inflacionario se pudiera tomar como ingreso no constitutivo de renta ni ganancia ocasional (Téllez Peñarete, 2019).

Pero sin dudas, la importancia de la Ley de financiamiento, para el objeto de este trabajo, gira en torno a las modificaciones que trajo al régimen tributario de la inversión de portafolio del exterior, régimen que no había sido modificado desde el año 2012. Las modificaciones presentadas a este régimen se pueden enlistar de la siguiente forma:

\section{Aplica tarifa especial de renta establecida en el Artículo 245 del Estatuto Tributario}

La modificación al numeral tercero del Artículo 18-1 del ET consiste en la adición de dos incisos en el cual se deja plasmado lo expuesto por la DIAN mediante el Concepto $\mathrm{n}^{\circ} .024422$ de 4 de septiembre de 2018 , en el 
sentido de dejar definido que para el inversionista de portafolio del exterior aplica la tarifa especial de renta establecida en el inciso primero del Artículo 245 del ET, cuando el ingreso corresponde a dividendos gravados de acuerdo con el parágrafo 2 del Artículo 49, es decir, al exceso de la utilidad máxima a distribuir como Ingreso No constitutivo de ingreso o ganancia ocasional, el cual tributa por el $25 \%$ y el remante tributa por el 7,5\%, aumentándose la tarifa que antes era del $5 \%$.

Esta tarifa especial también es aplicable cuando los dividendos se liquidan de acuerdo con lo dispuesto en el numeral 3 del Artículo 49 del ET, es decir, cuando se distribuyan a título de ingreso no constitutivo de renta o ganancia ocasional en cuyo caso la tarifa aplicable será del 7,5\%.

Sin embargo, se destaca que esta tarifa del 7,5\% solo es aplicable para las utilidades que fueran causadas y decretadas con posterioridad al $1^{\circ}$ de enero de 2019 , puesto que los dividendos causados y decretados en calidad de exigibles antes del 31 de diciembre de 2018 se gravarán a la tarifa que en su momento se encontraba vigente, es decir, la del 5\%, obviamente dependiendo de la clase de ingreso.

De otra parte, la DIAN, mediante los Conceptos 0042 de 2 de febrero de 2019 y 00612 de 13 de marzo de 2019, manifestó que de acuerdo con lo establecido en el Artículo 121 de la Ley de financiamiento, los dividendos que se distribuyan con cargo a utilidades causadas entre el $1^{\circ}$ de enero de 2017 y el 31 de diciembre de 2018 que no hubieren sido decretados en "calidad de exigibles" -noción que implica que se hubieran decretado en la Asamblea de Accionista y que no estén su- jetos a condición o plazo pues en ese evento no son exigibles- se les aplicarán las normas establecidas en la Ley 1943 de 2018, es decir, tributarán por la tarifa especial del 7,5\%.

\section{Reduce tarifa de renta en títulos de renta fija}

En relación con la tarifa general de las operaciones no se presenta modificación alguna, pues estas siguen tributando al 14\%. Sin embargo, se presenta una reducción a la tarifa aplicable a las utilidades obtenidas en los títulos de renta fija, bien sea públicos TES o privados- a un 5\%.

Conviene destacar que en principio el Gobierno solo buscaba reducir la tarifa de tributación respecto de las rentas obtenidas en los títulos de deuda pública-TES; sin embargo, en la ponencia para segundo debate presentada, se incluyó de igual manera a los títulos de renta fija privados; pese a que la exposición de motivos no se indica ninguna justificación, se puede decir que por la preponderancia e importancia que presentan estos títulos, además de que sin su inclusión se atentaría con el principio a la equidad entre emisores de este tipo de títulos.

Esta nueva tarifa de retención se debe aplicar a los rendimientos obtenidos en operaciones a partir del dos de enero de este año. Sin embargo, conviene destacar que, si el inversionista de los títulos de renta fija se encuentra localizado en una jurisdicción no cooperante, esta tarifa seguirá siendo del $25 \%$.

\section{Se incluyen normas de transparencia fiscal}

Se introducen algunos parágrafos al Artículo 18-1 del ET, los cuales presentan un 
objetivo en común, que este régimen especial no vaya a ser aplicable en últimas a un residente fiscal colombiano. Lo anterior busca que el beneficiario de la utilidad sea en realidad un extranjero o un no residente. El tercer parágrafo impone la obligación al administrador local de entregar a la DIAN la información que sea necesaria sobre el beneficiario final de la inversión.

El cuarto aclara que el régimen especial no es aplicable a las inversiones provenientes del exterior cuyo beneficiario final sea un residente fiscal que tenga control sobre dichas inversiones, para lo cual aclara en el parágrafo quinto que se entiende que un residente fiscal controla las entidades de inversión extranjera de acuerdo con los criterios de vinculación establecidos en el Artículo 260-1 del ET.

Se observa que la norma hace referencia al beneficiario final de la inversión mas no a la expresión del beneficiario efectivo, propia de los convenios para evitar la doble imposición. Sin embargo, analizando la finalidad y objetivo de la norma se podría concluir que se hace referencia al mismo sujeto, es decir, al sujeto que percibe el ingreso y que tiene toda la vocación para disponer del mismo. Al efecto, toca esperar si el decreto reglamentario define quién se entiende por beneficiario final y si esta figura tiene similitud con la del beneficiario efectivo.

\section{El inversionista extranjero de portafolio no es sujeto pasivo del nuevo impuesto al patrimonio}

El Artículo 35 de la Ley de Financiamiento establece un "nuevo impuesto al patrimonio", por las vigencias 2019, 2020 y 2021, el cual, de conformidad con el Artículo 40 de la misma ley, no puede ser deducible del impuesto sobre la renta. Entre los cambios que presenta este nuevo tributo se encuentra que consideró como sujetos pasivos a todas las sociedades extranjeras que no sean declarantes de renta en el país y que posean bienes en Colombia diferentes entre otros a las inversiones de portafolio del Artículo 18 -1 del ET, es decir, de la inversión de portafolio extranjero.

La no sujeción del impuesto al patrimonio para la inversión de portafolio no resultó una tarea fácil en el debate legislativo, puesto que la primera propuesta presentada por el Gobierno establecía al inversionista extranjero de portafolio como sujeto pasivo del tributo, y solo se estableció en la ponencia para segundo debate, cuya justificación radicó en la protección de la inversión extranjera-concretamente los fondos de inversión colectiva-, buscando minimizar los efectos de la reforma frente a este tipo de inversión y con ello, evitar los efectos cambiarios que pudiera ocasionar su retiro del país por cuenta del comentado impuesto.

Sin embargo, resulta importante destacar que la no sujeción al impuesto se presenta siempre y cuando se cumplan en debida forma las obligaciones previstas en el régimen cambiario vigente en Colombia, las cuales -como ya se explicó- radican en cabeza del Administrador local.

\section{Comportamiento de la inversión de portafolio extranjera tras la reforma introducida en el 2012}

Es prematuro indicar que por la reforma presentada en la Ley 1607 de 2012, el mer- 
cado de valores y concretamente la inversión de portafolio del exterior aumentó considerablemente las operaciones realizadas; sin embargo, no debe perderse de vista que el elemento impositivo es de gran relevancia a la hora de definir el tipo de inversión y el lugar en donde esta se realice.

En este punto es necesario llamar la atención sobre el reciente informe presentado por el Banco Mundial (2018), en el cual el indicador Doing Business -que mide anualmente $\mathrm{y}$ a nivel global la forma como las regulaciones nacionales favorecen o restringen la actividad empresarial y el ejercicio de derechos de propiedad- ubicó a Colombia entre 190 países en el puesto 59 , cediendo 4 puestos a la alcanzada en el 2016, siendo uno de los factores que determinaron dicha posición la alta carga impositiva que tiene el inversor en el país no solo frente a las obligaciones sustanciales sino también las formales.

Ahora bien, pese a lo expuesto anteriormente se debe decir que el mercado de valores ha tenido una tendencia evolutiva no solo en lo nacional sino también en el ámbito internacional, hasta el punto de llegar a convertirse en la herramienta más importante para el apalancamiento y desarrollo de las economías emergentes, como es el caso de Perú, Argentina, Brasil, México y Colombia. Claro ejemplo de ello, es el aumento que desde finales del siglo XX han presentado en las emisiones de deuda tanto pública como privada no solo el mercado colombiano sino también a nivel de la región, movimiento o dinámica que en Colombia se presenta en el sector financiero e industrial.

De acuerdo con el Banco Mundial, en el lapso de los años 2011-2015, las operaciones tranzadas de títulos de renta variable en algunos Estados de la región, fue significativa, tal como se refleja en la tabla 5 - cifras traídas de (Salcedo Younes, Téllez Peñarete y Castro Arango, 2017):

Así, se observa que en Latinoamérica los países donde las empresas locales más participan en el mercado de valores son Brasil y México, ya que la capitalización de mercado de empresas locales fue de USD \$490.534.110.000 en Brasil y de USD \$402.253.280.000 en México. En Colombia la participación de las empresas locales es más rezagada pero significativa, pues la capitalización de mercado de empresas locales

Tabla 5.

Operaciones tranzadas en América Latina - periodo 2011 - 2015

\begin{tabular}{|l|c|c|c|c|c|}
\hline \multicolumn{1}{|c|}{ País } & $\begin{array}{c}\text { Coeficientes } \\
\text { de operaciones } \\
\text { de acciones de } \\
\text { renta variable }\end{array}$ & $\begin{array}{c}\text { Capitalización } \\
\text { de mercado de } \\
\text { empresas locales } \\
\text { cotizadas (\% del } \\
\text { PIB) }\end{array}$ & $\begin{array}{c}\text { Capitalización de } \\
\text { mercado de empresas } \\
\text { locales cotizadas } \\
\text { (valor en dólares } \\
\text { estadounidenses) }\end{array}$ & $\begin{array}{c}\text { Valor total } \\
\text { de valores } \\
\text { negociados (\% } \\
\text { del PIB) }\end{array}$ & $\begin{array}{c}\text { Compañías } \\
\text { locales } \\
\text { cotizadas }\end{array}$ \\
\hline Argentina & $4,8 \%$ & $11,2 \%$ & 56.134 .630 .000 & 0,7 & $93 \%$ \\
\hline Brasil & $85,6 \%$ & $34,9 \%$ & 490.534 .110 .000 & 26,7 & $345 \%$ \\
\hline Chile & $13,5 \%$ & $90,4 \%$ & 190.352 .000 .000 & 10,5 & $223 \%$ \\
\hline Colombia & $10,3 \%$ & $38,8 \%$ & 85.955 .450 .000 & 4,6 & $69 \%$ \\
\hline México & $25,8 \%$ & $37,1 \%$ & 402.253 .280 .000 & 9,9 & $136 \%$ \\
\hline Perú & $2,6 \%$ & $38,9 \%$ & 56.555 .700 .000 & 1,6 & $212 \%$ \\
\hline
\end{tabular}

Fuente: Datos tomados del Banco Mundial (2016). 
fue de USD \$ 85.955.450.000 y en porcentaje del PIB fue del $38,8 \%$.

En Colombia la inversión extranjera de portafolio no es ajena a esta tendencia, ya que ha tenido un fuerte crecimiento en las operaciones respecto de los títulos participativos como en los de deuda, tranzados en bolsa. Esta evolución en el mercado se puede observar de una forma más drástica a partir del año 2013, según información reportada por las administradoras locales a la Superintendencia Financiera, el aumento en la transacción de títulos participativos y de deuda son los siguientes desde el año 2013 (Superintendencia Financiera, Cifras - Fondos de Inversión de Portafolio Extranjero, 2019) (véase tabla 6).

\section{Portafolio de Inversión Extranjera- En Títulos de Deuda}

Como se observa en la Tabla 6, desde el mes de febrero de 2013, momento en el cual la reforma del año 2012 ya llevaba un mes en vigencia, el portafolio de inversión extranjera respecto de la transacción de títulos de deuda tuvo un crecimiento considerable que no se había presentado en la historia del mercado de valores en Colombia, pues en dicho año la cifra ascendió en el mes de octubre a $\$ 4.607 .840$, tendencia que se mantuvo en el 2014 y 2015 llegando a una cifra record de $\$ 5.999 .835$.

En relación con el portafolio de inversión extranjera de títulos participativos, se observa que a partir del 2012, se han aumentado en los programas DRS las operaciones, reportándose una cifra récord en enero de 2013, es decir, en el mes que entró a regir la reforma
Tabla 6.

Comportamiento mercado de títulos de deuda. Portafolio de inversión extranjera en Colombia. Años 2013, 2014, 2015

\begin{tabular}{|c|c|c|}
\hline Año 2013 & Millones en pesos & Millones en dólares \\
\hline Enero & 3.765 .034 & $2.123,25$ \\
\hline Febrero & 3.945 .960 & $2.172,38$ \\
\hline Marzo & 3.551 .310 & $1.938,28$ \\
\hline Abril & 3.697 .429 & $2.021,79$ \\
\hline Mayo & 3.351 .990 & $1.772,15$ \\
\hline Junio & 3.713 .206 & $1.924,94$ \\
\hline Julio & 3.845 .490 & $2.034,30$ \\
\hline Agosto & 3.535 .107 & $1.826,52$ \\
\hline Septiembre & 4.007 .646 & $2.093,15$ \\
\hline Octubre & 4.607 .840 & $2.445,70$ \\
\hline Noviembre & 3.110 .666 & $1.610,18$ \\
\hline Diciembre & 3.221 .464 & $1.671,90$ \\
\hline Año 2014 & Millones en pesos & Millones en dólares \\
\hline Enero & 3.386 .635 & $1.686,35$ \\
\hline Febrero & 3.345 .085 & $1.627,86$ \\
\hline Marzo & 3.592 .852 & $1.828,13$ \\
\hline Abril & 4.374 .335 & $2.260,47$ \\
\hline Mayo & 4.261 .220 & $2.241,99$ \\
\hline Junio & 4.424 .745 & $2.352,10$ \\
\hline Julio & 4.755 .205 & $2.539,59$ \\
\hline Agosto & 4.367 .831 & $2.276,55$ \\
\hline Septiembre & 5.190 .703 & $2.558,91$ \\
\hline Octubre & 5.569 .702 & $2.716,24$ \\
\hline Noviembre & 5.632 .737 & $2.553,15$ \\
\hline Diciembre & 5.325 .020 & $2.225,75$ \\
\hline Año 2015 & Millones en pesos & Millones en dólares \\
\hline Enero & 5.817 .613 & $2.383,19$ \\
\hline Febrero & 5.999 .835 & $2.402,83$ \\
\hline Marzo & 5.790 .663 & $2.247,88$ \\
\hline Abril & 4.018 .433 & $1.682,72$ \\
\hline Mayo & 3.818 .238 & $1.506,93$ \\
\hline Junio & 3.607 .740 & $1.395,58$ \\
\hline Julio & 3.589 .128 & $1.252,30$ \\
\hline Agosto & 3.371 .583 & $1.087,22$ \\
\hline Septiembre & 3.317 .358 & $1.062,60$ \\
\hline Octubre & 3.375 .805 & $1.164,94$ \\
\hline Noviembre & 3.300 .760 & $1.064,38$ \\
\hline Diciembre & 3.218 .244 & $1.021,84$ \\
\hline
\end{tabular}

Fuente: Superintendencia Financiera, Cifras - Fondos de Inversión de Portafolio Extranjero (2019). 
de la Ley 1607 de 2012, en la suma de $\$ 9.213 .794$ y en los portafolios de títulos participativos la cifra de $\$ 19.560 .937$

De acuerdo con cifras suministradas por la entidad financiera Citibank Colombia S.A., se puede observar el comportamiento del portafolio de inversión extranjera en general (títulos de deuda y títulos participativos) tras la entrada en vigencia de la Ley 1607 de 2012, en el cual se observa que para el 2012, se transaron USD $\$ 3,23$ billones, en el 2013 se registraron USD $\$ 4,69$ billones, cifra que demuestra un aumento de USD \$ 1,46 billones. Sin embargo, en el año 2014, se alcanzó la cifra record de USD \$12,37 negociados y en el año 2016, pese a que no tuvo el crecimiento presentado en el año 2014, se mantuvo en USD $\$ 4,40$ billones, cifra que es superior a la obtenida en el año 2012. Lo anterior se puede ilustrar mejor forma así (véase gráfica 1).

Es necesario destacar que las cifras más altas reportadas en las operaciones de los portafolios de inversión extranjera se pre- sentan después de la reforma fiscal del año 2012, lo que si bien no puede decirse que ha sido el factor determinante que implicó este aumento - pues en el comportamiento del mercado de valores confluyen muchos aspectos no solo económicos sino también de naturaleza política, ambiental, social, etc.-, sí se puede indicar que ha sido un elemento importante para que el inversionista extranjero decida invertir en el mercado de valores colombiano, ya que al contar con normas fiscales claras y estables trasmite en el inversor confianza.

Sin embargo, pese al comportamiento presentado hasta el año 2016, se debe sentar la reflexión en relación con los títulos participativos, en los cuales se observa una reducción en el volumen o valor de los títulos transados, si se tiene en cuenta que, de acuerdo con cifras de la Superintendencia Financiera, en el primer trimestre del año 2013 se registraron las cifras más altas después de la reforma tributaria del año 2012, pues en enero se tranzaron $\$ 19.560 .937$, febrero fue de $\$ 18.828 .212$ y marzo $\$ 18.112 .217$.

\section{Gráfica 1.}

\section{Portafolio de inversión extranjera 2010 - 2016}

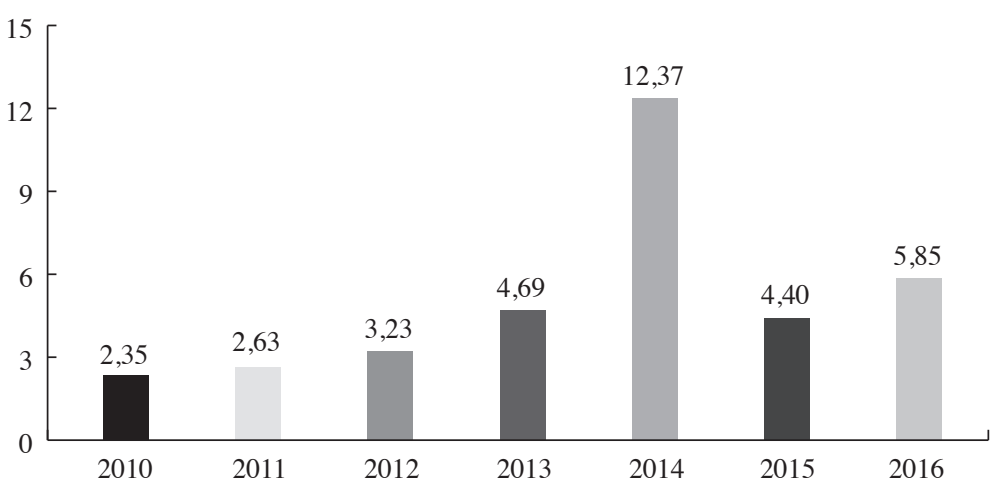

Fuente: Cifras proporcionadas por Citibank Colombia. 
En el año 2018 se redujo drásticamente el volumen de operaciones, registrándose las cifras más bajas en los últimos 5 años, al transarse en marzo de 2018 solo la suma de \$9.772.646, situación que se sigue presentado en agosto de 2018, en el cual la cifra es de solo $\$ 10.172 .215$.

La explicación a lo anterior puede tener una justificación netamente económica o política; sin embargo, puede decirse que se presenta por un indicio de índole tributaria, puesto que de acuerdo con la interpretación de la DIAN los dividendos para el inversionista extranjero se encuentran gravados con una tarifa efectiva del $28,75 \%$, siendo excesivamente alta en comparación con los mercados de la región, pues, como ya se vio, en países como Brasil y Perú la gran mayoría de operaciones realizas en el mercado público de valores por un extranjero o no residente se encuentran exentas.

De otra parte, si se hace un estudio del comportamiento del mercado en los años cuando se han tramitado reformas tributarias concretamente los últimos meses que son en los que se discute la misma, se puede observar una caída de la inversión de portafolio de los títulos de renta variable, en los cuales se reflejan cifras bajas, de la siguiente forma (véase tabla 7).

De acuerdo con lo anterior, se observa que en el 2014, a vísperas de la reforma de la Ley 1739 y cuya discusión tenía como punto central la creación de un nuevo impuesto a la riqueza en la que se pretendía gravar la inversión extranjera tanto directa como la de portafolio, el mercado de valores, concretamente el de portafolio de inversión extranjera, se resintió en los meses de noviembre y
Tabla 7.

\section{Comportamiento títulos de renta va-} riable. Inversión de portafolio extranjero en Colombia. Años 2014, 2016 y 2018

\begin{tabular}{|l|c|c|}
\hline \multicolumn{1}{|c|}{ Año 2014 } & $\begin{array}{c}\text { Millones } \\
\text { en pesos }\end{array}$ & $\begin{array}{c}\text { Cantidad de acciones } \\
\text { reportadas }\end{array}$ \\
\hline Enero & 13.023 .822 & 3.987 .297 .908 \\
\hline Febrero & 13.888 .399 & 4.010 .256 .205 \\
\hline Marzo & 15.705 .597 & 4.525 .204 .968 \\
\hline Abril & 15.580 .048 & 4.633 .410 .766 \\
\hline Mayo & 15.279 .840 & 4.371 .614 .007 \\
\hline Junio & 15.971 .386 & 4.561 .773 .898 \\
\hline Julio & 16.581 .290 & 4.802 .044 .427 \\
\hline Agosto & 17.415 .438 & 2.918 .921 .412 \\
\hline Septiembre & 16.590 .692 & 2.895 .035 .975 \\
\hline Octubre & 16.236 .089 & 2.977 .335 .188 \\
\hline Noviembre & 15.888 .606 & 2.799 .989 .299 \\
\hline Diciembre & 15.198 .311 & 2.683 .585 .737 \\
\hline \multicolumn{1}{|c|}{ Año 2016 } & $\begin{array}{l}\text { Millones } \\
\text { en pesos }\end{array}$ & Cantidad de acciones \\
\hline reportadas
\end{tabular}

Fuente: Superintendencia Financiera, Cifras - Fondos de Inversión de Portafolio Extranjero (2019). 
diciembre, registrándose las cifras más bajas en el mercado de títulos participativos.

Este panorama se repitió en el año 2018, cuando se observó una fuerte caída en el segundo semestre, indicándose, según las cifras de la Superintendencia Financiera, las cifras más bajas en los meses de septiembre y octubre siendo solo de $\$ 9.602 .258$ y $\$ 9.060 .363$, periodo en el cual se estaba discutiendo la conocida Ley 1819 de 2016.

En relación con la inversión de portafolio del exterior en el mes de noviembre y diciembre del año 2018, se registró un retroceso en el mercado del 37,3\% de USD $\$ 3.173$ millones en el 2017 a USD $\$ 1.990$ millones (primera página, 2018), periodo en el cual se discutía la ley de financiamiento, presentándose una gran incertidumbre frente a las modificaciones que se pudiera presentar al régimen fiscal en Colombia y concretamente a los regímenes especiales como lo es en este caso el portafolio de inversión extranjera.

Esto puede llevar a concluir que la incertidumbre fiscal que ha presentado la inversión de portafolio extranjero en Colombia implica necesariamente que el inversionista ante el posible cambio de reglas en el tratamiento fiscal rescate su capital invertido en el país y decida sacarlo. Lo anterior se demuestra con el comportamiento del mercado en los años 2014 y 2018, en los cuales se tramitaron reformas en las que se pretendía en principio gravar con el impuesto a la riqueza a los inversores de portafolio del exterior.

\section{Conclusiones}

El mercado financiero y en concreto el mercado de valores dentro del cual se ha- lla la inversión extranjera que se maneja a través de portafolio, ha suscitado un mayor crecimiento en las últimas décadas, tal como lo indican las cifras registradas por la Superintendencia Financiera, las cuales demuestran un crecimiento desde el año 2013, fueron superiores a las registradas en años anteriores al 2012. Lo anterior se debe a que este mercado se ha convertido en una gran herramienta para obtener recursos por parte de los Estados, evitando el endeudamiento del sector real y permitiendo con ello la circulación o flujo de capitales.

Sin embargo, al realizar un estudio minucioso de la regulación fiscal especial del portafolio de inversión extranjera, se pueden presentar varias conclusiones. En primer lugar, se observa una constante derivada en la volatilidad legislativa fiscal que existe, pues cada dos años se están realizando reformas tributarias cuyo común denominador es el recaudo de fondos para poder solventar los gastos sociales que demanda el país, los cuales cada vez son más altos. Esta necesidad lleva a que el inversionista (directo como de portafolio) no tenga la intención de dejar su capital en el país por un largo tiempo.

Incide tanto la regulación fiscal en el mercado de valores y concretamente en la de inversión extranjera de portafolio, que de acuerdo con la cifras de la Superintendencia Financiera, se puede observar la forma como se afecta el mercado en los meses en los que se discute una reforma tributaria, es decir,el segundo semestre del año y claro ejemplo de ello se vio reflejado en el año 2018, cuando se presentaron la cifras más bajas no vistas desde antes de la reforma tributaria de la Ley 1607 de 2012, respecto de la transacción de los títulos de renta variable, cayendo 
la inversión de portafolio extranjero en un $37,3 \%$. Lo anterior se pudo presentar por el impuesto al patrimonio que en un principio gravaría a los inversionistas extranjeros de portafolio y que fue retirado en la ponencia para primer debate en el Congreso.

Lo anterior demuestra cómo la incertidumbre fiscal afecta al inversionista extranjero y le resta al mercado de valores colombiano protagonismo en comparación con los demás mercados de la región. A modo de ejemplo, medidas como gravar los dividendos de los títulos de renta variable transados en la Bolsa de Valores implica claramente un desincentivo para el inversionista extranjero y una desventaja al ver mejores posibilidades para invertir en países como Perú o Brasil, en los cuales la mayoría de operaciones realizadas en bolsa (sin importar que sea inversionista extranjero) se encuentran exentas de impuestos directos o gravados a tarifa cero.

Se considera que la mejor forma para hacer del mercado de valores atractivo para la inversión extranjera de portafolio deriva no solo en tener tarifas bajas de imposición - que en este caso sería tratar de dar a las rentas obtenidas en estas operaciones una tratamiento de rentas exentas-, sino en hacer del ordenamiento tributario un régimen con normas claras y sobre todo estables cuya temporalidad no dependa de la necesidad de recaudo del Gobierno de turno.

La segunda conclusión que se puede exponer a raíz de este trabajo, es el desarrollo legislativo que ha tenido el régimen especial fiscal de la inversión de portafolio, que se ha dado en respuesta a la evolución de este mercado. La Ley 1607 de 2012, por medio de la cual se estableció un régimen tributario especial para las operaciones realizadas a través de este portafolio, ayudó a solucionar muchas asimetrías que se presentaban entre el inversionista residente en Colombia y el extranjero, dotando al sistema tributario de normas claras y efectivas para gravar al inversionista por sus rentas obtenidas en este mercado.

Aspectos tales como considerar al inversionista extranjero contribuyente, establecer una base gravable depurada para cada operación financiera, practicar la retención en la fuente por una sola vez por parte del Administrador Local, permitirle amortizar las pérdidas obtenidas sin lapso, poder aplicar al inversionista extranjero respecto de la renta proveniente del portafolio de inversión los CDI suscritos por Colombia, son aspectos que permitieron dar solución a los problemas de arbitraje fiscal que se presentaba y que ayudaron a mejorar el desarrollo de este tipo de mercado.

De igual forma, los esfuerzos propuestos con la reforma del año 2012 se ven opacados con las consecuencias colaterales que trajeron para la inversión extranjera de portafolio las reformas tributarias de los años 2016 y de 2018, en relación con el impuesto sobre los dividendos, en virtud de las cuales se grava este tipo de ingreso para el inversionista extranjero de portafolio en una tarifa del $25 \%$ más un 7,5\% al exceso de la utilidad máxima a distribuir como ingreso no constitutivo de renta o ganancia ocasional y de un 7,5\% cuando se distribuyen a título de ingreso no constitutivo de renta o ganancia ocasional.

Sin embargo, no debe perderse de vista que la posibilidad que tiene el inversionista extranjero residente fiscal de un Estado con 
el que Colombia tiene suscrito un CDI de aplicarlo, en su rol como contribuyente, es un gran avance que permite en cierta medida mitigar los efectos de la alta tributación que se encuentra establecida, pero ello no resulta del todo una medida efectiva si se tiene en cuenta que, por ejemplo, Colombia solo tiene suscritos quince convenios entre los cuales no se encuentran países como Estados Unidos, Alemania, Japón y Reino Unido.

Todo lo anterior lleva a tener presente que el mercado de capitales frente a la inversión de portafolio del exterior en Colombia ha tenido un significativo avance en materia legislativa, pero aún resulta corto, si se tiene en cuenta que en los países de la región en este sentido se encuentran más desarrollados en razón a que se cuenta con un marco normativo fiscal más benevolente para el inversionista extranjero, permitiéndole tener certeza de las normas tributarias que en el tiempo van a regir en sus operaciones, demostrando así confianza y estabilidad económica.

Una solución a estas asimetrías que se presentan en los diferentes mercados de capitales de la región podría solucionarse establecimiento normas tributarias generales a nivel comunitario a través del Mercado Integrado Latinoamericano - MILA, creándose acuerdos comunitarios de desarrollo económico y bursátil en los cuales se establezcan tarifas homogéneas en los países que lo integran, se minimicen las obligaciones formales al inversionista y se establezcan beneficios tributarios comunes, todo con el ánimo de hacer el mercado de valores latinoamericano más competitivo frente a los mercados norteamericano y europeo.

\section{Bibliografía}

Abella Abondano, G. y Quiroga Barreto, G. (2008). Sistema de Negociación y Registro de Valores y de Compensación y liquidación de valores. (F. d. Universidad de los Andes, Ed.) Revista de Derecho Privado, 39.

Álvarez Zárate, J. y Grando, M. (2013). Estado y Futuro del Derecho Económico Interncional en América Latina. Evolución del derecho internacional Económico en América Latina (pág. 43). Bogotá: Universidad Externado.

Amador Cabra, L.; Monroy Cely ,D. y Blanco Varón , C. (2014). Serie de Derecho Económico del Derecho, nuevas vertientes y diferntes aplicaciones. Bogotá : Universidad Externado de Colombia.

Ariza Marín,E.L. (2007). Doctrina de la Autorregulación del Mercado de Valores en Colombia 2001-2006. Bogotá: Bolsa de Valores de Colombia y Autorregulador del Mercado de Valores de Colombia.

Atehortúa , J. A. (2014). Mercado de Capitales y Portafolios de Inversión. Medellín.

Banco Mundial (2016). Obtenido de http://data. worldbank.org/

Blanco Barón, C. (primer trimestre de 2015). Revista de Economía Institucional, 17 No 32, 261.

Blanco Serrano, J. (2006). Mercado público de valores pasado, presente y futuro. En S. Rodríguez Azuero, E. Rincón Cárdenas y J. Calderón Villegas (Edits.), Temas de derecho financiero contemporaneo (pág. 543). Bogotá: Universidad del Rosario.

Calderón Villegas, J. (2006). El Alcance del concepto de información provilegiada en Colombia: una aproximación a partir de la regulación del mercado público de valores. En S. Rodríguez Azuero, E. Rincón Cárdenas y J. Calderón Villegas (Edits.), Temas de derecho Financiero Contemporaneo (págs. 505-540). Bogota: Universidad del Rosario.

Castro Arango, J. (2016). El Concepto de dividendo en los Convenios de doble imposición (Primera ed.). Bogotá: Universidad Externado de Colombia.

CEPAL - Naciones Unidas (2016). Portal de inversión social. Obtenido de https://observatoriosocial.cepal. org/inversion/es/paises/colombia 
Concepto DIAN n ${ }^{\circ} .18752,18752$ (Dirección de Impuestos y Aduanas Nacionales -DIAN 15 de julio de 2016).

Concepto ${ }^{\circ} .1147$ (2016).

Concepto $\mathrm{n}^{\circ} .2002027703$ (Superintendencia Financiera 4 de junio de 2002).

Concepto $\mathrm{n}^{\circ} .24422,2422$ (Dirección de Impuestos y Aduanas Nacionales -DIAN 4 de septiembre de 2018).

Conceptos 20056-946 y 2010007643 (Superintendencia Financiera 27 y 19 de julio y marzo de 2005 y 2010).

Congreso de la República (1990). Exposición de Motivos Ley 49 de 1990.

Congreso de la República (2015). Gaceta.

Congreso de la República (2018). Gaceta n ${ }^{\circ} .933$. Bogotá.

Córdoba, M. (2015). Mercado de valores. 4. Bogotá: Ecoe ediciones.

De la Torre, A. y Schmukler, S. (2008). Mercados de capitales emergentes y la globalización "la experiencia en América Latina”. Banco Mundial.

economico, O. p., \& OCDE . (2010). Modelo de Convenio Tributario sobre la renta y sobre el patrimonio (version abreviada). OCDE, Comite de Asuntos Fiscales. Paris: Instituto de Estudios Fiscales.

Fradique Méndez, C. (2014). Guía del Mercado de Valores. Bogotá, Colombia: Brigard \& Urritia y Bolsa de Valores de Colombia.

Insignares, R.; Piza , J., \& Zornoza , J. (2001). Curso de Derecho Fiscal (Vol. Tomo I). Bogotá, Colombia: Universidad Externado de Colombia.

Insignares, R. (2015). Cuantificación de la obligación tributaria. En J. R. Piza, R. Insignares, \& Otros, Curso de Derecho Fiscal (Vol. I, pág. 466). Bogotá, Colombia: Universidad Externado de Colombia.

Jiménez Mejía, J., Higuita Naranjo, J., \& Otros,. (2012). Estudio Teórico Práctico de la Reforma Tributaria Ley 1607 de 2012 y sus Decretos Reglamentarios. Bogotá: Crowe Horwath.

Larrota Acevedo, J. (mayo de 2008). Las operaciones bursátiles en la normatividad colombiana: El problema de la traducción jurídica. (U.d. Andes, Ed.) Revista de Derecho Privado, 39, 6.
Marín Elizalde, M. (2015). Los sujetos de la obligación tributaria. En J. R. Piza , R. Insignares y otros (Ed.), Curso de Derecho Fiscal (pág. 431). Bogotá: Universidad Externado de Colombia.

Marín Erizalde, M. (2015). Los sujetos de la obligación tributaria. En J. R. Piza (Ed.), La Obligación Tributaria y sus Fundamentos Constitucionales (págs. 347-394). Bogotá, Colombia: Universidad Externado de Colombia.

Ministerio de Hacienda de España (2019). España. Convenios De Doble Imposición (25-01-2019). Obtenido de http://www.hacienda.gob.es/es-ES/Normativa\%20y\%20doctrina/Normativa/CDI/Paginas/ CDI_Alfa.aspx

Ministerio de Hacienda y Crédito Público, de Colombia (s.f.). Ministerio de Hacienda y Crédito Público. Obtenido de http://www.minhacienda.gov.co/HomeMinhacienda/ShowProperty; jsessionid=nIgraKIjJKf mzuBozGpMR9L10xTaya4GFm_ig8D1ksLcE4CE_6 zI!508618735? nodeId=\%2FOCS\%2FMIG_6012612. PDF\%2F\%2FidcPrimaryFile\&revision=latestreleased

Monroy Cely, D. A.; Amador Cabra, L. A. y Banco Varón, C. (2014). Serie de Derecho económico, Análisis Económico del Derecho, nuevas vertientes y diferentes aplicaciones. Bogotá, Colombia: Universidad Externado de Colombia.

Mundial, B. (octubre de 2018). Doing Business. Obtenido de http://www.doingbusiness.org/content/ dam/doingBusiness/media/Annual-Reports/English/ DB2018-Full-Report.pdf

OCDE, p. (2014). Plan de acción contra la erogación de la base imposible y traslados de beneficios.

Oficio, $\mathrm{n}^{\circ} .012100$ (Direccion de impuestos y Aduanas Nacionales -DIAN 5 de mayo de 2018).

Oficio $n^{\circ}$. 2018120946-003, 2018120946-003-000 (Superintendencia Financiera 5 de octubre de 2018).

Piza Rodríguez , J.R. (2010). Curso de Derecho Tributario, procedimiento y régimen sancionatorio. Bogotá, Colombia: Universidad Externado de Colombia.

Piza, J.R.; Insignares, R. y Sarmiento Pérez, P. (2010). Impuesto sobre la renta y complementarios. Consideraciones teóricas y prácticas. Bogotá: Universidad Externando de Colombia.

Primera página (7 de diciembre de 2018). www.primerapagina.com.co. 
Ramírez Molinares, C. (2011). Marco Jurídico de la Inversión Extranjera en Colombia. Saber, Ciencia y Libertad, 163-177.

República de Colombia (2014). Gaceta n ${ }^{\circ} .575$.

Rodríguez Fernández, M. (julio - diciembre de 2014). Concepto, alcance y estructura de la autorregulación en el mercado de valores colombiano. E - Mercatoria, $13, N 2,29-96$.

Rohatgi, R. (2008). Principios Básicos de los Tributación Internacional. (J. M. Idrovo, Trad.) Bogotá: Legis.

Romero, Y. A. (2009). Los ADRs como mecanismo de acceso al mercado internacional de capitales. Bogotá, Colombia: Universidad la Sabana.

Salcedo Younes, R. Y. (2010). Tratamiento Tributario de los Instrumentos Financieros (IDF). En M. P. Vega, Manual de Derecho Tributario Internacional (pág. 388). Bogotá: Temis.

Salcedo Younes, R. Y.; Téllez Peñarete, L. E. y Castro Arango, J. M. (2017). Tributación de los Mercados de Capitales en América Latina. (M. Montes Ferrando, Ed.) Bogotá: Instituto Colombiano de Derecho Tributario - ICDT.

Sentencia C-173, C- 173 (Corte Constitucional 10 de marzo de 2010).

Sentencia C-406 de 2004 (Corte Constitucional 4 de mayo de 2004).

Sentencia C-692 (Corte Constitucional 5 de septiembre de 2007).

Sentencia Exp. 2015-0026 (Tribunal Administrativo de Cundinamarca 13 de octubre de 2016).
Sentencia Exp. 21883 (Consejo de Estado - Sección Cuarta 11 de mayo de 2017).

Superintendecia Financiera (2008). Concepto Básico del Mercado de Valores. Bogotá, Colombia.

Superintendencia Financiera (2019). Cifras - Fondos de Inversión de Portafolio Extranjero. Obtenido de https://www.superfinanciera.gov.co/inicio/informesy-cifras/cifras/portafolios-de-inversion-61326

Superintendencia Financiera (s.f.). www.superfinanciera.gov.co/SFCCant/Glosario/. Recuperado el 13 de febrero de 2017, de Glosario.

Téllez Peñarete, L. E. (2019). Impacto de la Ley de financiamiento en el sector financiero. En J. M. Castro Arango y O. L. González Parra (Edits.), Comentarios a la Ley de Financiamiento (pág. 249). Bogotá, Colombia: Universidad Externado de Colombia.

Uckmar, V. y Corasantini , G. (2010). Manual de Derecho Tributario Internacional. Bogotá: Temis.

Ustariz , L. H. y Ustariz , J. F. (2015). Los fondos de inversión colectiva y el negocio de custodia (Segunda ed.). Bogotá: Ibáñez.

Valdez Acosta, R. (2001). Curso de Derecho Tributario. Bogotá: Temis S.A.

Vega Borrero, F. A. (2003). Las medidas contra el Treaty Shopping. Las cláusulas de limitación de los beneficios en los CDI. (Ministerio de Hacienda, Ed.) Madrid: Instituto de Estudios Fiscales.

Fecha de recepción: 6 de junio de 2019

Fecha de aprobación par 1: 23 de julio de 2019

Fecha de aprobación par 2: 4 de agosto de 2019 